\title{
Electoral Pressures for Change: The effect of POLITICAL REFORM
}

\section{Introduction}

A cartoon in the Asahi Shinbun dated 11 August 1993 shows the leaders of the seven political parties participating in the Hosokawa coalition government formed two days before. They are wielding samurai swords and standing triumphant on the inert body of a dinosaur labelled 'single party control'. One of the leaders is holding a banner that reads: 'Next is political reform', and the caption to the cartoon expresses the following sentiment: 'By launching [the new Cabinet], “One Great Task” has been completed' (Asahi Shinbun, 11 August 1993).

At the time it was easy to regard the formation of the first non-Liberal Democratic Party (LDP) Cabinet for nearly 38 years as a heroic event. A party mired in corruption, preferring backstage deals to open government and massively influenced by irresponsible bureaucrats and self-serving interest groups had been vanquished by a coalition of far-sighted reformers. These reformers were proposing a coherent programme to democratise and modernise the political, economic and social systems and practices of Japan. As happens following most revolutions, however, what ensued was far more messy and confusing, the politics more murky and the achievements more ambiguous than the initial mood of euphoria would have predicted. Indeed, within a mere nine months of losing office, the LDP dinosaur had revived, and though much less powerful than before, was taking its first steps on the road to regaining its dominant political position.

The Hosokawa Cabinet adumbrated a reform agenda whose principal elements were deregulation, decentralisation, economic reforms and a radical change to the electoral system for the House of Representatives. In the event, partly because the tenure of office of his government was so brief, Hosokawa's only solid achievement in the area of political reform was a wholesale rewriting of the electoral law for the Lower House. ${ }^{1}$ Although, however, this was arguably the one really major political change that took place in the $1990 \mathrm{~s}$, to gauge its effects is far more problematic. Indeed, it is a central argument of this paper that the effects of changing the Lower House electoral system have been quite limited, and that the causes of the most crucial political changes of the 1990s must be sought largely elsewhere. (It is possible, of 
course, that the new electoral system may produce more substantial effects in the future, but in any case we cannot assume that the new system will not be further revised in the next few years.)

\section{Conceptualising the politics of the $1990 \mathrm{~s}$}

For many observers, the predominant impression of Japanese politics in the 1990s has been one of utter confusion. Political parties have split, amalgamated, changed their names, switched coalitions, appeared, disappeared, re-appeared - with barely discernible rhyme or reason. Politicians who were sworn enemies become bosom friends, and bosom friends become sworn enemies. Ideological difference or similarity seems to have little predictive value in relation to coalition behaviour. Political leaders whose images are strong show little leadership when given the opportunity, whereas apparently weak leaders demonstrate an unexpected capacity to lead (or at least to lead more than was expected of them). Bureaucrats control politicians, but politicians control bureaucrats, and pressure groups of all kinds both manipulate and are manipulated by both bureaucrats and politicians. Superficially at least, Japan's political system is a vast amorphous organism, pulsating and constantly changing shape, but lacking clear direction or internal distinctions that can be readily grasped. Rules exist, but rarely seem to determine outcomes.

There is, however, a pattern that informs the political events of the 1990s. The fact that this pattern has been difficult to discern may well relate to the way the problem has been expressed by various participants and observers of the political process in the 1990s. In the opinion of Ozawa Ichiro, the most high profile reformer of the decade, the political choice is between a continuation of single-party dominance (essentially the system up to 1993), and a two-party alternation. The great advantage of two-party alternation, according to this argument, is that the electorate is given a genuine choice between two alternative sets of politicians having different political philosophies and programs. This is democratically desirable, in that it gives a genuine choice to the electorate. It is also desirable in terms of getting things done, since with a single party permanently dominant, vested interests make it exceedingly difficult to change entrenched policies. Such a system has a tendency toward corruption, toward economic policies distorted by the influence of narrow groups occupying a strategic position and, in a pithy phrase, 'crony capitalism'. 
Ozawa did his best to bring into being an alternative party that would be capable of challenging the LDP. His most impressive effort in this regard was the formation of the Shinshinto (New Frontier Party), an amalgamation of several pre-existing parties that was launched in December 1994 but ignominiously collapsed a mere three years later, in December 1997. It reached the height of its popularity at the House of Councillors elections of July 1995, ${ }^{2}$ but subsequently suffered a steady trickle of defections and was beset by increasingly difficult problems of internal cohesion. The reasons for all this need not detain us. Whether, given somewhat different circumstances, the Shinshinto might have developed into an alternative government to the LDP is academic. The hard fact is that it did not.

Just before the general elections for the House of Representatives held in October 1996, another serious opposition party, the Minshuto (Democratic Party of Japan: DPJ) was formed, with aspirations to be an alternative party of government. It too was an amalgamation of different groups, having a more left-of-centre orientation than the Shinshinto, but most contemporary observers would probably agree that its chances of forming an alternative government are substantially slimmer than those of the Shinshinto in its heyday.

On the other hand, an important political innovation of the 1990s (though not entirely without precedent) is coalition government. We shall examine below the varieties of coalition government, and the electoral and other conditions that have led to them. But at this point we need to advance the most important proposition of the paper, namely that the politics of the 1990s may be conceptualised as a clash between two opposing principles.

The first is the principle of single-party dominance, in which the LDP has far more parliamentary seats than any other party, and other parties, rather than acting as an opposition, operate without power in a role supportive of the dominant party. A partial example would be the Hashimoto government between October 1996 and the early months of 1998, when the Social Democratic Party (SDP, formerly Japan Socialist Party, or JSP) and Sakigake - both very weak following the October 1996 general elections - lent their support to the LDP without participating in government. But more broadly, this principle means that power rests essentially within one political organisation (party), and other parties either act as satellites round the LDP sun, or maintain a position of impotent opposition (for instance the Japan Communist Party, or JCP).

The opposing principle is that of a coalition government: that is to say, where different parties join together in a coalition arrangement, and there is a genuine sharing of political power between them. Such an arrangement will only take place where the LDP (or, theoreti- 
cally, another dominant party) lacks a parliamentary majority. An example from the middle of the decade is provided by the LDP-JSP-Sakigake coalition under Prime Minister Murayama between June 1994 and January 1996. Although from various perspectives this was not the most impressive of governments, it was one where a variety of political perspectives were allowed free play, and political debate within government about contentious policy issues became important. ${ }^{3}$ It is true, of course, that the experience of the Murayama and subsequent Hashimoto coalition governments was electorally catastrophic for the Socialists, ${ }^{4}$ but at the time the style of government was notably different from what had normally prevailed under LDP single-party rule.

Our contention is that it is an understanding of the complex process of interaction between these competing principles that can bring conceptual order into the admittedly highly confused politics of the 1990s. On the one hand, the LDP, having lost its parliamentary majority in 1993-94 (as the result of large-scale defections), and having gone into opposition, set out to re-establish its dominant political position. To a remarkable extent, the party has been successful in this ambition. By June 1994 it was back in government, as part of a coalition government; in January 1996 it regained the prime ministership; in the Lower House elections of October 1996 it won about 30 new seats, while remaining short of a majority; in September 1997 it found itself once again with a Lower House majority in its own right; and by 1999 the LDP had a fairly comfortable Lower House majority. The one prize that remained elusive was the regaining of a majority in the House of Councillors, and indeed in the elections to that House, held in July 1998, the LDP lost seats. Consequently, the LDP can only continue in office in what the Japanese press describes as a situation of 'stable government' (Asahi Shinbun, 10 September 1999), that is if it enters into coalition arrangements with other parties that may be quite different from it in core constituency, organisational structure and policy preference. ${ }^{5}$

How then does the present situation differ from that which prevailed between 1955 and 1993, a period which is generally regarded one of single-party dominance? First of all, we have to enter the caveat that the political system during those years was not unchanging; in particular, from 1989 the LDP lacked an Upper House majority. But secondly and more importantly, the 1990s have seen some important developments that have effected major changes in the way Japanese politics operates.

Arguably the change that has been the most far-reaching in its effects has been the near demise of the Japan Socialist Party (now Social Democratic Party). In January 1993 the JSP had 141 (out of 512) seats in the House of Representatives and 73 (out of 252) seats in the House 
of Councillors. By 1999 the corresponding figures for the SDP (same party under a new name) were 14 and 14. Even though the JSP had enjoyed varying fortunes during the period of LDP dominance up to the early 1990 s, it had always been the leading party of opposition, with sufficient parliamentary numbers to block constitutional revision (when it teamed with other smaller parties). More broadly, nobody expected the Socialists to become popular enough to take power (at least, not on their own). Nevertheless, their presence as a constant veto block, backed by public sector unions, intellectuals, teachers and others, acted as a balancing force against the ambitions of right-wing LDP politicians desirous of reversing certain aspects of the Occupation settlement of the late 1940s and early 1950s. Issues of peace and war were most prominent, and a kind of tacit agreement ensured the integrity of the Japan-US security relationship, but maintained strict limitations on Japan's use of military force.

In essence, this was an agreement premised on the continuance of the Cold War. When the Cold War ended, the rationale for such a balance to continue was weakened. By ironic circumstances, the Socialists, riding high in the polls at the outset of the 1990s, were rapidly declining in electoral strength just as the opportunity came to participate in a series of coalition governments with varying partners. This in turn accelerated the process of decline. Many of their votes plainly went to the Communists, who continued to act like an opposition and have been gaining in electoral strength from a low base. The main point for our argument, however, is that a party that for years had represented a limited but effective veto force, had by the late 1990s almost disappeared.

As a result of the near-demise of the Socialist Party and the return to strength of the LDP, there has been a distinct but subtle shift in the nature of political debate across a range of issues. The trend that has been accorded the largest amount of publicity - and occasioned disquiet in some quarters - is a perceptible shift to the right of the balance of opinion in the political class. One telling example is the recent decision of the parliament (July 1999) to conduct a debate on the 1946 Constitution for the first time in its history. ${ }^{6}$

On the other hand, there is evidence of an opening up of debate on a range of issues where outcomes are difficult to classify as 'right wing'. For instance, the Freedom of Information Act passed through Parliament in its 145th session that ended on 13 August 1999. That session proved one of the most varied, as well as active, parliamentary sessions of recent years, and included, among others, an ambitious bill to cut back the number of government ministries from 23 to $13 .{ }^{7}$ It is beyond the scope of this paper to develop a full analysis of why the most recent parliamentary session should have been so active. To explain it would involve 


\section{Pacific Economic Papers}

considering the narrower spectrum of opinion within the political class, as well as the substantial rewriting of the political agenda that began with the Hosokawa Cabinet in 1993 (although it is possible to trace the changes to an earlier time than that). The pressures caused by the Asian economic crisis and various foreign policy problems would also need to be taken into account.

\section{Coalition government in the 1990s}

We now need, however, to enter into a discussion of the second principle of Japanese politics in the 1990s, that of coalition government. There have been a variety of coalition arrangements since 1993, but what is significant is that despite the LDP's successes in clawing back dominant political power since 1994, it has remained dependent upon entering into coalition with other parties in order to secure passage through parliament of its legislative programme. Up until September 1997 this was because it lacked a majority in the House of Representatives, and the Lower House is of course the more important of the two. But crucially, the LDP has lacked a majority in the House of Councillors ever since its defeat in the Upper House elections of July 1989, in the aftermath of the Recruit Scandal.

Until the upheaval of 1989, it had been widely assumed that the House of Councillors was of little significance for either government or opposition. Indeed, with the LDP in control of both houses, as it was between 1955 and 1989, this was largely the case. In law, however, the Upper House has the power to reject legislation sent to it from the Lower House (except for the budget, treaties and the designation of a new prime minister). While the House of Representatives may override an Upper House rejection if it does so by a two-thirds majority, governments do not normally have a Lower House majority as large as that. ${ }^{8}$

'Stable government' relies on a majority in both houses of parliament, and this dictates the need to create coalition regimes. Apart from the minority Hata government, which lasted a mere nine weeks between April and June 1994, every government of the 1990s has enjoyed a Lower House majority (although some have been more comfortable than others). On the other hand, several governments have lacked an Upper House majority. This was an embarrassingly difficult problem for the Kaifu (LDP) government at the time of the Gulf crisis and war in 199091. At that time the LDP Secretary-General, Ozawa Ichiro, attempted to make deals with certain parties in opposition (especially the Komeito) in order to secure Upper House approval of a peacekeeping operations bill. This did not succeed at the time, although it led to an agreement after the war was over, in 1992. 
It is instructive to examine the degree to which the variously composed governments from 1993 were 'secure' in terms of their majority (of lack of it) in the two houses. This can be seen from the tables attached as appendices to this paper, but the following is a brief summary. The figures throw considerable light on the rationale for the formation of various kinds of coalition.

The Miyazawa (LDP) government as of January 1993 controlled 53.5 per cent of Lower House seats, but only 42.1 per cent of Upper House seats (Table A1.2). Following substantial defections from the LDP in June 1993 and the defeat in the House of Representatives elections in July, a coalition government was formed under Hosokawa Morihiro, consisting of seven parties and one Upper House grouping, but excluding the LDP. The Hosokawa government had a bare majority (50.7 per cent) of Lower House seats, and 52.0 per cent of seats in the Upper House (Table A1.3). Even though it could control both houses, its majority was so thin in both that legislative success was premised on the maintenance of greater parliamentary discipline among its own often squabbling ranks than it was readily able to command.

The next government, headed by Hata Tsutomu, was, as we have seen, in a minority in both houses (35.6 per cent of seats in the House of Representatives) (Table A1.4). It was tolerated for some nine weeks essentially because a government was required in order to pass the budget, which had been delayed. Many observers expressed astonishment at the formation, and subsequent ability to survive, of the three-party coalition governments (LDP, JSP and Sakigake), led successively by Murayama Tomiichi (JSP) and Hashimoto Ryutaro (LDP), between June 1994 and the first Lower House elections under a reformed electoral system in October 1996. The LDP and JSP were ancient enemies, so that an alliance between them appeared to go against nature. When, however, we inspect the parliamentary arithmetic of these governments, we see that their formation and maintenance made a great deal of sense from the perspective of the participants. A month after the formation of the Murayama government (July 1994), it commanded 57.8 per cent of seats in the House of Representatives, and approximately 63.5 per cent of House of Councillors seats (see Table A1.5). ${ }^{9}$ The figures changed little over 18 months of that government (58.5 per cent and 63.9 per cent in January 1995 (Table A1.6); 56.9 per cent and 60.7 per cent in August 1995 (Table A1.7)).

When the prime ministership was taken over by Hashimoto (and thus the LDP) in January 1996, the figures initially remained much the same (57.3 per cent and 59.5 per cent) (see Table A1.8). The general elections for the House of Representatives held in October 1996, under the new election system, produced, on the other hand, a more complicated situation. The 


\section{Pacific Economic Papers}

JSP (now the SDP), split shortly before the elections, leading to the formation of the Minshuto (Democratic Party of Japan, or DPJ). As a result, the Socialists were reduced to a mere rump of 15 seats. Moreover the Sakigake party was almost wiped out as a result of the election, ending up with only two Lower House seats. The upshot was that the SDP and Sakigake remained in alliance with the LDP but did not participate in government. The LDP gained seats in the election but not enough to form a government in its own right. It could only survive provided it was able to rely on the parliamentary support of the two parties that had now left the government. Thus the Hashimoto government, as of November 1996, now commanded only 46.6 per cent of Lower House seats, although with Socialist and Sakigake seats added, the figure rose to a bare majority: 51.0 per cent. In the House of Councillors, the government as such was now short of a majority (44.0 per cent), but was much better off when the votes of the two parties supporting it were added (56.7 per cent) (Table A1.9).

Over the next year and a half the position of the Hashimoto government in the House of Representatives gradually improved, largely as a result of defections to the LDP from other parties on the principle of 'getting with the strength'. By the end of September 1997, Japan's largest political party had just 50 per cent of the seats in the Lower House, and when the support of the SDP and Sakigake is added, the total rises to 53.4 per cent. A majority still eluded it in the Upper House, where on its own it commanded 44.4 per cent of the seats. With the seats of the two supporting parties, it held 54.0 per cent of the Upper House (Table A1.10).

What is evident from these figures is that even though the parliamentary position of the LDP was improving, the Hashimoto government was in a substantially less comfortable parliamentary position for the year following the October 1996 general elections than in the months preceding it. The LDP continued to attract a trickle of defectors from other parties, and by January 1998 the picture looked rosier. The LDP controlled 51.8 per cent of Lower House seats in 1998 ( 55.2 per cent when adding the seats belonging to its two supporting parties ), and 47.2 per cent of Upper House seats (56.7 per cent when we include SDP and Sakigake seats) (Table A1.11). These defections were severely disrupted by the results of the July 1998 elections for half the seats in the House of Councillors when the Hashimoto government suffered the blame for the banking indebtedness crisis, the economic recession and rising levels of unemployment.

With the consequent resignation of Hashimoto as prime minister, his successor, Obuchi Keizo, began his government controlling a slightly improved majority in the House of Representatives (52.6 per cent of total seats), but a very poor position in the House of 
Councillors (42.1 per cent) (Table A1.12). The SDP and Sakigake had abandoned their support for the LDP government before the elections, so that the LDP was now once more on its own in government. The period of coalition arrangements crossing the Left-Right divide appeared to be over.

The Obuchi government thus started out with an unsustainable parliamentary position. It was likely to be severely frustrated in attempts to realise its legislative program, being so far short of a majority in the Upper House. Such a situation, especially for a government facing an economic crisis, called for the forging of a new coalition alliance. This was, in part at least, accomplished with the signing in November 1998 of a coalition agreement with Ozawa's Jiyuto (Liberal Party). The Jiyuto had been formed by a small group of Ozawa loyalists following the collapse of the Shinshinto, and advocated relatively radical policies of political reform. The new coalition gave to the Obuchi government a cast iron majority in the House of Representatives (59.6 per cent) - although this was still not large enough to override obstruction by the House of Councillors. The Jiyuto, however, was weak in the Upper House, and the two parties together accounted for only 46.0 per cent of seats there (Table A1.13).

This situation explained the negotiations that took place in August and September 1999, with a view to forming a three-party coalition government including the Komeito as well as the LDP and Jiyuto. If this coalition materialises, the Obuchi government will enjoy a comfortable majority in the House of Councillors, and a massive majority (for the first time more than the two thirds required to revise the Constitution $)^{10}$ in the House of Representatives. On the other hand, other parties have found the Komeito (with its monolithic and cohesive organisation closely linked with the Soka Gakkai Buddhist sect) difficult to work with in the past. ${ }^{11}$ It appears that the negotiations have been proving difficult, with the Komeito and Jiyuto taking opposed positions on the question of reducing the number of Lower House members, among other issues.

This suggests that while progress with re-establishing the fact of the LDP's dominance has been substantial, it can only be achieved through the construction of coalitions with other parties, which may well prove awkward partners. The 1990s have given politicians a good deal of experience with coalition government, including its requirement for compromise in relation to both policy and the structure of policymaking. In terms of the two principles proposed earlier in this paper, while aspiring to single-party dominance, LDP politicians are facing the practical reality of having to adjust to the much more demanding reality of coalition arrangements. This 


\section{Pacific Economic Papers}

has begun to create a more dynamic and less stereotyped policymaking environment than that which prevailed under the 1955 political system with its Cold War dichotomies.

\section{The impact of electoral reform}

What part, then, has electoral reform played in the political process of the 1990s? It has seemed necessary to analyse in some detail the political dynamics of the decade before dealing with the effects of electoral reform, simply in order to distinguish changes caused by reforming the electoral system from changes whose causes lie elsewhere.

As suggested earlier in the paper, the principal concrete achievement of the Hosokawa government was reform of the electoral system for the House of Representatives, and associated tightening of the laws related to political corruption. Even though the relevant laws did not come onto the statute book until late in 1994 when the Murayama Cabinet was in office, the shape of the reforms were basically decided, at times through difficult negotiation and compromise between contending interests, by the Hosokawa Cabinet itself. It needs to be stressed, however, that the new system was in a fundamental way the product of compromise, and turned out to be far less radical in its impact that some reformers expected and hoped.

In order to explain the rationale for this last assertion, we need first to give a brief description of the former system, followed by a short examination of the new system, including the way it worked in the elections of October 1996.

The former electoral system for the House of Representatives was used in every election between 1947 and 1993 (a total of 18 general elections). A rather similar system operated between the 1920s and the war. Although some details were changed from time to time, the essence of it was that each elector had a single, nontransferable vote, but each constituency elected several members. For most of the period of the system's validity, there were roughly equal numbers of three-, four- and five-member constituencies, though latterly a small number of two- and six-member constituencies were created. It was a system based on SNTV in MMCs (single nontransferable vote in multi-member constituencies).

Broadly speaking, the system resulted in certain political consequences. ${ }^{12}$ First, although this was not a system of proportional representation, by comparison with either the British or Australian Lower House electoral systems, it contained a strong proportional element. This was because since a candidate might well be elected with a mere 15 or 20 per cent of the total vote in a constituency, minority parties commanding approximately that proportion 
of the vote across a number of constituencies might expect to maintain a significant parliamentary representation. ${ }^{13}$

Second, in the case of a large party such as the LDP, which might expect to win several seats in particular constituencies, different candidates of the same party in the same constituency were competing with each other as much as they were competing with candidates of other parties. In the particular case of the LDP this accentuated (although it probably did not cause) factional divisions within the party. It also led to a situation where each candidate maintained a personal support group (koenkai) of constituency electors for the purpose of promoting his (or her) campaign, but had weak or nonexistent links with the party as such. ${ }^{14}$ The central party organisation had an important role in ensuring that not too many candidates bearing the LDP label stood in any particular constituency. In this, it was generally effective.

Third, competition between different candidates of the same party seems to have encouraged what in Japan is delicately called 'money politics', or in stronger words, corruption. In part because of the electoral system and in part because of lax anti-corruption laws, astonishing amounts of money were spent on elections.

Fourth, however, it is arguable that the often intense intraparty competition stimulated by the electoral system acted to increase the LDP vote. Candidates for smaller parties (including the Socialists), mainly standing as sole candidates for their party in their constituencies, would in many cases scarcely need to campaign, since they could rely on their organisational backers (e.g. labour unions) to deliver a sufficient proportion of the vote to get elected. This, together with the fact that the various opposition parties were incapable of combining into a single party, greatly favoured the LDP.

Fifth, the former electoral system was marred by severe problems of malapportionment. Migration of people from the countryside to the cities was inadequately reflected in constituency boundary correction. Although palliative corrections were made from time to time, there were periods when the discrepancy in the value of a vote between the most favoured and least favoured constituency was more than four to one. By favouring the rural areas, this malapportionment (the 'negative gerrymander') was advantageous to the LDP.

The advertised purposes of abandoning SNTV in MMCs and moving to a new system were to get rid of money politics, shift the emphasis of electoral campaigning from personality-based appeals to appeals based on policy choices, and create a politics that should be genuinely competitive between parties. Some advocates, notably Ozawa, consciously wished to move to a system of two-party alternating politics (Ozawa 1994:66). What actually emerged, however, 


\section{Pacific Economic Papers}

was the hybrid product of intense bargaining and compromise between different political interests and principles. Parties on the conservative side of the spectrum in the main wished for a system predominantly based on single-member constituencies and first-past-the-post voting, whereas the smaller parties of the centre and left wished to maximise the number of seats that should be determined by proportional representation.

The result was a compromise between the two, with the weighting, however, toward the former. The total seat number was reduced from 511 to 500 , of which 300 were to be elected from single-member constituencies, and the remaining 200 from 11 regional blocs by the d'Hondt system of proportional representation. Each elector was to have two votes, one for each type of seat. The same candidate could stand for both constituencies. If elected in both, he or she would take the seat won in a single-member constituency, so that the regional bloc seats came to be seen as a kind of second best. The regional bloc seats, however, constituted a crucial second chance for candidates unable to muster the plurality required to win a single-member seat. Moreover, in a peculiar arrangement, parties could distribute of seats among their candidates in the regional PR blocs depending on the candidates' relative margins of defeat in the singlemember constituencies that are located in the same area as the regional bloc. ${ }^{15}$

The effect of this arrangement, even though not all parties took advantage of it, was to bring back an important characteristic of the former (SNTV in MMCs) electoral system for the Lower House. Under the old system, a candidate commanding a relatively minor proportion of votes in a given constituency was often able to be elected, given that the first three, four, or five candidates in terms of their proportion of the vote, were declared elected. The 'margin of defeat' rule in the new electoral system in effect made it possible once again for a candidate who failed to win a seat in a single-member constituency to win a seat in a regional bloc depending on how well the candidate had performed in the single-member constituency. This was neither a true first-past-the-post, nor a true proportional representation system, but an underhand way of resuscitating one of the key elements of the former system.

Ozawa had been trenchant in his criticism of this aspect of the old electoral arrangements. In his words:

In the present electoral system, each district throughout the country elects from three to five representatives. Invariably, at least one opposition candidate wins a seat even if he never appears in public ... Extraordinarily, it is the opposition parties that enjoy the greatest security in this setup. The largest, the Socialist Party, seems convinced that there 
is no need to go through the struggle of actually campaigning to win an election. The Socialists will never rule, left as they are. What is more, they seem content with that. It makes one wonder why they are a party at all. It is the multi-seat district system that has so indulged the opposition parties, particularly the Socialists. As a consequence of their weakness, the LDP has been assured of its semi-permanent rule so that it, too, has become immobilized. (Ozawa 1994:64)

\section{Conclusion}

Since this was written, the Socialists have been more or less eliminated from the political picture. Nevertheless, it seems evident that the much-heralded electoral reforms of 1993-94 have been much less radical in their effect than appeared at first sight. Apart from the technical factors outlined above, the tightening of the anti-corruption laws does not seem to have had a great effect of eliminating money politics, even though the State now provides a proportion of electoral funding to parties. The koenkai system still reigns supreme, and indeed the need in single-member constituencies to win a plurality (not just 20 per cent of the vote) has led to ever bigger koenkai. The alternative opposition parties formed since the change in the system have either collapsed (Shinshinto), or failed to take off (DPJ).

In the absence of a single viable opposition party, the single-member constituencies are extremely advantageous to the LDP, and in this sense privilege the single-party dominance principle that this paper discussed earlier. The less numerous regional PR blocs are where smaller parties are able to carve out a niche for themselves, but elements in the ruling establishment would like to reduce their number still further. On their own, these regional blocs are incapable of privileging the alternative principle that we advanced earlier, that of coalition government. Indeed, if the Japanese parliament were a single-chamber parliament, the LDP would have re-established its political dominance fair and square. The House of Councillors, however, has proved to be a very significant actor in the politics of Japan after the LDP defeat in the Upper House elections of 1989. A decade later, moreover, it remains the principal institution compelling the Obuchi government to enter into coalition arrangements. This is ironic, since the electoral system for the House of Councillors is even less reconstructed than that of the House of Representatives. But the electorate is sophisticated enough to be adept at using Upper House elections as a means of checking governmental power without 


\section{Pacific Economic Papers}

actually removing the LDP from power. Moreover, given that only half of the Upper House members are renewed at each election, regaining control of it cannot happen quickly. ${ }^{16}$

The 1990s have not led, as reformers earlier in the decade hoped, to a system based on two-party alternation, and it seems unlikely that this can be achieved in Japan. It has led, however, to coalition governments and a challenging of the dominance of a single party. Even though there is absolutely no guarantee of the future success of this challenge, it seems currently the best guarantee of a healthier political system. Faced with economic crisis in the late 1990s, as well as difficult issues to resolve in the areas of foreign policy, the future of social welfare and the structure of government, the record of successive governments has been mixed. Nevertheless, the role of parliament in the promotion of reform across a range of areas has become more lively and vigorous, and legislative innovation makes it, not before time, an institution to watch.

The continuance of such a healthy trend is not guaranteed. Neither is the continuance of political balance guaranteed, since the dangers of a radical shift of the centre of gravity to the nationalist Right are real. Given the weakening of the traditional Left, right-wing politicians are showing signs of flexing their ideological muscles with greater freedom than before. Electoral reform has had only a limited impact on these issues. But even though the electoral system remains to a very large extent unreconstructed, the electorate holds in its hands the one possibility of enforcing a democratic system of checks and balances against excesses of political power and ambition: that of forcing governments to enter into coalitions and thus take other views into account.

\section{Notes}

1 The relevant laws, including a revision of laws relating to corrupt practices in electoral campaigns, did not come onto the statute books until late in 1994, well after the demise of the Hosokawa government, but it was that government that negotiated the basic agreement to change the system.

The Shinshinto polled 30.75 per cent of the vote in the national constituency and 26.47 per cent of the vote in the prefectural constituencies. This surpassed the LDP vote percentages, which were 27.29 per cent in the national constituency, and 25.40 per cent in the prefectural constituencies. The LDP still ended up with substantially more seats (107 as against 56 for the Shinshinto) because only half the seats were being renewed (Asahi Nenkan, 1996, pp. 255-6). 
For only the second time in Japanese political history, the prime minister was a Socialist, and the deputy prime minister, Kono Yohei, was the only president of the LDP not to become prime minister.

Murayama notoriously abandoned long-held Socialist rejection of the Self-Defence Forces, the Japan-US Security Treaty, the national anthem and national flag. This, in all probability, was the primary cause for the later loss of much of his party's core constituency.

In September 1999 Prime Minister Obuchi was actively negotiating with the Komeito to form a three-party coalition of LDP, Jiyuto (Ozawa's Liberal Party) and Komeito.

Other important examples are the legalisation of the flag and anthem (both having right-wing connotations) in August 1999, and the passage of a wiretapping bill in the same month. It is debatable how far a move to the right among the political class is reflected in the electorate as a whole. Much has been made of the election of Ishihara Shintaro - a celebrated right winger - as governor of Tokyo prefecture in April 1999. But Ishihara only won 30.6 per cent of the total vote in $1999(1,646,549)$ against five significant opponents who split the vote between them, as against 43.9 per cent of the total vote $(2,336,359)$ in 1975 , when he came second (Asahi Nenkan, 1976, p. 259; Asahi Shinbun, 12 April 1999). (The figures for the 1999 election are provisional, with 97 per cent of the vote counted.)

$7 \quad$ For a comprehensive list of the bills passed in the 145th session of parliament, see Asahi Shinbun 13 and 14 August 1999. The success rate of government bills was 87 per cent.

Constitution, Article 59, paragraph 2. In paragraph 3 of the same article, there is a provision for the calling of a joint committee of both houses, but this is not a fail-safe method of ensuring the passage of legislation from a government's point of view. For a fuller discussion, see Stockwin (1999:113-16).

9 Loyalties in the Upper House were fluid at the time, so the figure is approximate.

10 Article 96 of the 1946 Constitution requires a concurring majority of two-thirds of the members of each house of parliament voting separately, followed by a simple majority in a referendum of the people.

11 One important cause for the collapse of the Shinshinto in December 1996 was the failure of the Komeito elements to assimilate fully into that artificially created party.

12 This is not to argue that such consequences were inevitable, but rather that in the particular political circumstances of Japan between 1947 and 1993 these consequences were observable.

13 By contrast the Democratic Labor Party maintained a little under 20 per cent of the vote in several constituencies for the House of Representatives in Victoria, Australia, between the late 1950s and the early 1970s, but never won a single Lower House seat.

14 This need not necessarily be seen as an inevitable consequence of SNTV in MMCs. It is possible to imagine a situation where the central party organisation coordinated the campaigns of its several candidates in the same constituency, dividing up the constituency into districts in such a way as to optimise the effectiveness of the party vote and avoid vote wastage. The fact is, however, that this did not happen in Japan. 


\section{Pacific Economic Papers}

15 For details of how this worked, see Stockwin (1999:130-1).

16 The remarkable significance of the House of Councillors during the Obuchi government was stressed by Sarah Hyde in the 'Survey of Domestic Politics, 1998-99', delivered at the seventh annual Japanese Politics Colloquium, University of Birmingham, 7-9 September 1999.

\section{References}

Asahi Nenkan (various years), Asahi Shimbunsha, Tokyo.

Ozawa, Ichiro (1994) Blueprint for a New Japan, Kodansha International, Tokyo, New York and London.

Stockwin, J.A.A. (1999) Governing Japan: Divided Politics in a Major Economy Blackwell, Oxford. 


\section{Appendix}

Table A1.1 Checklist of coalition governments in the $1990 \mathrm{~s}$

\begin{tabular}{|c|c|c|}
\hline Prime Minister & participating parties & dates \\
\hline \multicolumn{3}{|c|}{ Lower House elections, July 1993} \\
\hline \multirow[t]{8}{*}{ Hosokawa } & JSP & Aug. 93 - April 94 \\
\hline & Shinseito & \\
\hline & Komeito & \\
\hline & JNP & \\
\hline & DSP & \\
\hline & Sakigake & \\
\hline & Shaminren & \\
\hline & Minkairen (Rengo) & \\
\hline Hata & $\begin{array}{l}\text { The above parties, minus: } \\
\text { JSP and Sakigake }\end{array}$ & April - June 94 \\
\hline \multirow[t]{3}{*}{ Murayama } & LDP & June 94 - July 95 \\
\hline & JSP & \\
\hline & Sakigake & \\
\hline \multicolumn{3}{|c|}{ Upper House elections, July 1995} \\
\hline \multirow[t]{3}{*}{ Murayama } & LDP & July 95 - Jan. 96 \\
\hline & JSP & \\
\hline & Sakigake & \\
\hline \multirow[t]{3}{*}{ Hashimoto } & LDP & Jan. - Oct. 96 \\
\hline & JSP & \\
\hline & Sakigake & \\
\hline \multicolumn{3}{|c|}{ Lower House elections, October 1996} \\
\hline \multirow[t]{3}{*}{ Hashimoto } & LDP & \\
\hline & [JSP] -supporting & Oct. $96-98$ \\
\hline & [Sakigake] gov't but not in it & \\
\hline \multicolumn{3}{|c|}{ Upper House elections, July 1998} \\
\hline \multirow{2}{*}{ Obuchi } & LDP & \\
\hline & Liberal Party (Jiyuto) & Jan. $99---$ \\
\hline Obuchi & Above parties + Komeito & Sept.- Oct. 99---- \\
\hline
\end{tabular}


Pacific Economic Papers

Table A1.2 Parliamentary seat breakdown by party, 20 January 1993 [Miyazawa Kiichi, prime minister]

\begin{tabular}{lrr}
\hline & House of Representatives & House of Councillors \\
\hline & 274 & 106 \\
JDP & 141 & 73 \\
Komeito & 46 & 24 \\
JCP & 16 & 11 \\
DSP & 13 & 11 \\
Rengo & - & 11 \\
Niin Club & - & 5 \\
JNP & - & 4 \\
Independent & 7 & 7 \\
Vacant & 15 & 0 \\
Total seats & 512 & 252 \\
Total gov't seats & 274 & 106 \\
\hline
\end{tabular}

Note: $\quad$ Parties in bold = government parties

Source: Asahi Nenkan, 1994, p. 116.

Table A1.3 Parliamentary seat breakdown by party, 6 August 1993 [Hosokawa Morihiro, prime minister from 9 August]

$\begin{array}{lrr}\text { LDP } & 227 & 99 \\ \text { JSP } & 76 & 73 \\ \text { Shinseito } & 60 & 8 \\ \text { Komeito } & 52 & 24 \\ \text { JNP } & 35 & 4 \\ \text { DSP } & 19 & 11 \\ \text { Sakigake } & 13 & - \\ \text { Shaminren } & 4 & - \\ \text { Minkairen (Rengo) } & - & 11 \\ \text { Niin Club } & - & 5 \\ \text { JCP } & 15 & 11 \\ \text { Independent } & 10 & 6 \\ \text { Total seats } & 511 & 252 \\ \text { Total gov't seats } & 259 & 131\end{array}$

Note: $\quad$ Parties in bold = government parties.

Source: $\quad$ Asahi Nenkan, 1994, p. 118. 
No. 301 March 2000

Table A1.4 Parliamentary seat breakdown by party, 26 April 1994 [Hata Tsutomu, prime minister]

House of Representatives

$\begin{array}{lr}\text { LDP } & 206 \\ \text { Kaishin* } & 130 \\ \text { JSP } & 74 \\ \text { Komeito } & 52 \\ \text { Sakigake } & 15 \\ \text { JCP } & 15 \\ \text { Mirai } & 5 \\ \text { Seiun } & 3 \\ \text { Independent } & 9 \\ \text { vacancy } & 2 \\ \text { Total seats } & 511 \\ \text { Total gov't seats } & 182\end{array}$

Note: * An amalgam of Shinseito, Kaikaku, DSP, Shinto Club, Liberal Party, and Kaikaku no kai. The JSP and Sakigake defected from the coalition as a result of the formation of Kaishin, which excluded them.

Parties in bold = government parties.

Source: $\quad$ Asahi Shinbun, 26 April 1994.

Table A1.5 Parliamentary seat breakdown, 18 July 1994

[Murayama Tomiichi, prime minister]

\begin{tabular}{lrc}
\hline & House of Representatives & House of Councillors \\
\hline LDP & 200 & \\
Kaishin & 126 & 95 \\
JSP & 74 & 68 \\
Komeito & 52 & 24 \\
Sakigake & 21 & 1 \\
JCP & 15 & \\
Koshikai & 6 & 38 \\
Mirai & 5 & 5 \\
Shinryokufukai & & 5 \\
Niin Club & & 6 \\
Liberal & 10 & 252 \\
Independent & 2 & $160[+?]$ \\
vacancy & 511 & \\
Total seats & 295 & \\
Total gov't seats & & \\
\hline
\end{tabular}

Note: $\quad$ Parties in bold = government parties.

Source: Asahi Nenkan, 1995, p. 248. 
Pacific Economic Papers

Table A1.6 Parliamentary seat breakdown, 20 January 1995 [Murayama Tomiichi, prime minister]

\begin{tabular}{lcc}
\hline & House of Representatives & House of Councillors \\
\hline LDP & 208 & 95 \\
Shinshinto & 176 & 47 \\
Heiseikai* & & 66 \\
JSP & 70 & 15 \\
Sakigake & 21 & 11 \\
Shinryokufukai & 15 & 5 \\
JCP & 3 & 5 \\
Minshu Shinto Club & & 8 \\
Niin Club & 14 & 252 \\
Liberal & 4 & 161 \\
Independent & 511 & \\
vacancies & 299 & \\
Total seats & & \\
Total gov't seats & & \\
\hline
\end{tabular}

Notes: * An alliance of Shinshinto and Komeito-derived members in the Upper House; parties in bold $=$ government parties.

Source: $\quad$ Asahi Nenkan, 1996, p. 241.

Table A1.7 Parliamentary seat breakdown, 4 August 1995

[Murayama Tomiichi, prime minister]

House of Representatives

Shinshinto

Heiseikai

JSP

Sakigake

Shinryokufukai

JCP

Minshu no kai

Niin Club

Minshu Shinto Club

Mushozoku Club

Heiwa Shimin

Independent

vacancy

Total seats

Total gov't seats
207

169

64

20

15

5

3

3

14

11

511

291
House of Councillors

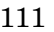

68

39

3

5

14

4

2

6

252

153

Note: $\quad$ Parties in bold = government parties.

Source: Asahi Nenkan, 1996, p 244. 
Table A1.8 Parliamentary seat breakdown, 20 January 1996 [Hashimoto Ryutaro, prime minister]

\begin{tabular}{lcc}
\hline & House of Representatives & House of Councillors \\
\hline LDP & 207 & 111 \\
Shinshinto & 170 & 68 \\
Heiseikai & & 36 \\
SDP (JSP) & 63 & 3 \\
Sakigake & 23 & 4 \\
Shinryokufukai & & 14 \\
JCP & 15 & 4 \\
Shimin Forum & 8 & 3 \\
Shin Shakaito & 2 & 4 \\
Niin Club & 2 & 2 \\
Mushozoku no kai & 2 & 2 \\
Jiyu Rengo & 5 & \\
Independent & 14 & 252 \\
vacancy & 511 & 150 \\
Total seats & 293 & \\
Total gov't seats & & \\
\hline
\end{tabular}

Note: $\quad$ Parties in bold = government parties.

Source: Asahi Nenkan, 1997, p. 175.

Formation of Democratic Party of Japan (DPJ - Minshuto), September 1996

First HR elections under new electoral system, October 1996

Table A1.9 Parliamentary seat breakdown, 29 November 1996 [Hashimoto Ryutaro, prime minister]

\section{LDP}

Shinshinto

Heiseikai

DPJ (Minshuto)

$\underline{\mathrm{SDP}}$ (JSP)

JCP

21 seiki

Niin Club

Sakigake

Mushozoku Club

Shin Shakaito

Independent

Total seats

Total gov't seats

Total 3-party alliance seats
238

152

52

15

26

5

2

10

500

238

255
111

65

(DPJ/Shinryokufukai) 14

29

14

4

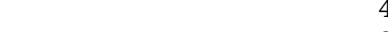

3

5

252

111

143

Notes: $\quad$ Parties in bold = government parties; parties underlined = parties supporting the government, but not taking office.

Source: $\quad$ Asahi Nenkan, 1997, p 180. 
Pacific Economic Papers

Table A1.10 Parliamentary seat breakdown, 29 September 1997 [Hashimoto Ryutaro, prime minister]

\begin{tabular}{lcc}
\hline & House of Representatives & House of Councillors \\
\hline LDP & 250 & 112 \\
Shinshinto & 129 & 59 \\
Heiseikai & 52 & 23 \\
DPJ & 15 & 21 \\
SDP (JSP) & 26 & 14 \\
JCP & 10 & 3 \\
Taiyoto (Sun Party) & 5 & 4 \\
Niin Club & & 4 \\
Mushozoku no kai & 2 & 3 \\
Jiyu no kai & & 3 \\
Sakigake & 11 & 6 \\
Shin Shakaito & 500 & 252 \\
Independent & 250 & 112 \\
Total seats & 267 & 136 \\
Total gov't seats & & \\
Total 3-party alliance seats & & \\
\hline
\end{tabular}

Notes: $\quad$ Parties in bold = government Parties; parties underlined = parties supporting the government, but not taking office.

Source: $\quad$ Asahi Nenkan, 1998, p. 179. 
Collapse of Shinshinto, December 1997

Formation of Jiyuto (Liberal Party) by Ozawa Ichiro, December 1997

Table A1.11 Parliamentary seat breakdown, 12 January 1998

[Hashimoto Ryutaro, prime minister]

House of Representatives

House of Councillors

$\begin{array}{lrr}\text { LDP } & 259 & 119 \\ \text { Minyuren } & 98 & 41 \\ \text { Heiwa Kaikaku } & 46 & \\ \text { Komei } & & 25 \\ \text { Jiyuto } & 42 & 12 \\ \text { JCP } & 26 & 14 \\ \text { SDP (JSP) } & 15 & 21 \\ \text { Sakigake } & 2 & 3 \\ \text { Mushozoku no kai } & 2 & \\ \text { Niin Club } & & 4 \\ \text { Shin Shakaito } & & 3 \\ \text { Kaikaku Club } & 9 & 3 \\ \text { Independent } & 1 & 252 \\ \text { vacancy } & 500 & 119 \\ \text { Total seats } & 259 & 143 \\ \text { Total gov't seats } & 276 & \\ \text { Total 3-party alliance seats } & & \end{array}$

Notes: $\quad$ Parties in bold = government parties; parties underlined = parties supporting the government, but not taking office.

Source: $\quad$ Asahi Nenkan, 1999, p. 171. 
Pacific Economic Papers

Expansion of DPJ, absorbing other groups, April 1998

House of Councillors elections, July 1998

Table A1.12 Parliamentary seat breakdown, 30 July 1998

[Obuchi Keizo, prime minister]

\begin{tabular}{lrr} 
LDP & 263 & 106 \\
DPJ & 92 & 55 \\
Heiwa Kaikaku & 47 & \\
Komei & & 24 \\
Jiyuto & 40 & 12 \\
JCP & 26 & 23 \\
SDP & 14 & 14 \\
Mushozoku no kai & 5 & 3 \\
Sakigake & 2 & 4 \\
Niin Club & & 3 \\
Kaikaku Club & & 8 \\
Independent & 9 & 252 \\
vacancy & 2 & 106 \\
Total seats & 500 & 3 \\
Total gov't seats & 263 & 3 \\
\hline
\end{tabular}

Note: $\quad$ Seats in bold = government seats.

Source: $\quad$ Asahi Nenkan, 1999, p. 174.

Re-emergence of Komeito as a single party, November 1998

Table A1.13 Parliamentary seat breakdown, 27 November 1998 [Obuchi Keizo, prime minister]

House of Representatives

$\begin{array}{lrr}\text { LDP } & 263 & 104 \\ \text { DPJ } & 93 & 55 \\ \text { Komeito } & 52 & 24 \\ \text { Jiyuto } & \mathbf{3 5} & \mathbf{1 2} \\ \text { JCP } & 26 & 23 \\ \text { SDP } & 14 & 14 \\ \text { Mushozoku no kai } & 5 & 11 \\ \text { Sangiin no kai } & & \\ \text { Sakigake } & 2 & 5 \\ \text { Niin Club } & 4 & 252 \\ \text { Independent } & 10 & 116 \\ \text { Total seats } & 500 & \\ \text { Total gov't seats } & 298 & \end{array}$

Note: $\quad$ Seats in bold = government seats

Source: Asahi Nenkan, 1999, p. 177. 
The M inistry of Finance (MOF) at the Crossroads

\author{
Jennifer A myx \\ Australian $\mathrm{N}$ ational $\mathrm{U}$ niversity
}





\section{Contents}

Introduction

Pressures on the M OF in the 1990s

2.6

The financial supervisory agency (FSA): independent but initially constrained ........................................................................... 2.8

From relational to rule-based regulation 2.11

I mplications for patterns of policymaking interaction 2.16

Conclusion 2.20

$\mathrm{N}$ otes

R eferences

2.26 
FigURES

Figure 2.1 Establishment of the financial supervisory agency (FSA) (22 June 1998)

Figure 2.2 Japan's new financial regulatory structure (October 23, 1998) .................................................... 2.14

Figure 2.3 Planned changes in the financial regulatory structure (J uly 2000) 


\section{The Ministry of Finance (MOF) at the Crossroads}

\section{Introduction}

Since the collapse of a speculative asset bubble in 1991, Japanese banks have been burdened with enormous amounts of nonperforming loans. The failure of the Ministry of Finance (MOF) to tackle this problem aggressively had grave repercussions as macroeconomic policy mistakes sank the economy into prolonged recession and exacerbated the magnitude of bad bank loans. A full-blown financial crisis hit in 1997, following the collapse of the nation's tenth largest bank and the fourth largest securities firm, and continued until late 1998.

Once cited as the most capable technocracy in the world, the MOF was implicated in this regulatory breakdown and the ensuing crisis. As a result, the Diet transferred the ministry's inspection and supervisory authority over private sector finance to a newly created Financial Supervisory Agency in June 1998. A distinctive characteristic of Japan's system of financial regulation, however, has long been its overwhelming reliance on informal means to achieve policy goals. The Ministry of Finance (MOF), entrusted with the regulation of private sector finance until June 1998, sat at the intersection of a dense and pervasive web of ties extending to financial institutions, the Diet and other government agencies. These ties involved opaque and exclusionary relationships that blurred lines between public and private actors. The change in formal organisational structures brought about by the June 1998 transfer was therefore on its own not sufficient for effecting far-reaching change. A shift in the primary orientation of government authorities from promoters and coordinators to monitors and prudential regulators required changes in both the formal and informal institutions of governance.

This paper argues that the October 1998 Financial Revitalisation Law and related bills provided the necessary complement to earlier reform of formal regulatory structures by displacing informal institutions of problem resolution with universally extending legislative schemes. Moreover, this legislative package effectively severed the network of relational ties that had inhibited more aggressive tackling of the nation's nonperforming loan problem. ${ }^{1}$ In these ways, the financial revitalisation package effected an almost revolutionary shift from 
a system of opaque relationship-centred financial regulation to one of objective and transparent rules-based regulation.

This paper first reviews the pressures that came to bear on the MOF in the 1990s and led to change in formal regulatory structures. It then highlights the limitations of reform carried out only at the formal institutional level. The paper next turns to identify those provisions in the Financial Revitalisation Law and related bills that empowered the FSA to act for the first time as a truly effective prudential regulator and that fundamentally altered the dynamics surrounding financial regulation in Japan. Finally, the paper considers the implications of recent reform in the financial regulatory structures for the MOF's informal relational ties in other areas and the financial policymaking process in general.

\section{Pressures on the MOF in the 1990s}

From 1991 to 1995, Japan's general economic downturn - rather than the large amount of nonperforming loans held by Japanese banks - captured the attention of the voting public and topped the MOF's policy agenda. Within the ministry, the nonperforming loan problem was perceived as a reflection of problems with corporate Japan, rather than indicative of problems in the banking sector in particular (Author interview with MOF official, 1999). When bank inspections by MOF officials in 1992 revealed that some banks were creating paper companies as temporary havens for nonperforming assets, the MOF decided to look the other way. ${ }^{2}$ Optimistic about the prospects for an economic rebound and operating under the assumption that an improved business environment would turn such bad assets into good, ministry officials viewed the creation of paper companies as a reasonable 'interim measure'. With such a measure, revealing the true magnitude of the nonperforming loan problem to the public was unnecessary and banks could continue to serve as a buffer between corporate Japan and the real economy. Depositor panic was also staved off.

Disclosure to the public of the severity of the nonperforming loan problem would also have jeopardised the MOF's position as a largely autonomous decision maker in this policy sector. While the Diet necessarily approved all financial legislation, the structure of the nation's electoral system and paucity of legislative staff long gave national elected representatives incentives to focus their political resources in times of perceived financial stability on more locally based niches of the economy. The MOF had therefore been entrusted with much discretion in filling in the details of broad and vaguely worded laws with ministerial 
regulations and administrative notices. Private sector actors were given written notifications or informal verbal instructions from the ministry - a practice known as 'administrative guidance' (gyosei shido).

The economy did not rebound, however, and the magnitude of nonperforming loans ballooned in the ensuing years. The protracted decline in land prices and the stock index also meant that the value of collateral continued to drop along with the value of bank equity holdings. By 1995 the mounting nonperforming asset problems plaguing the jusen (nonbank housing and loan corporations financially imperilled with the collapse of the bubble) made their collapse imminent without government support. If simply allowed to fold, however, some of the jusen's financiers - most notably the nokyo agricultural cooperatives - would also fail. Due to the political clout of the agriculture lobby, this was unacceptable to the LDP and the use of public funds appeared the only solution.

The MOF's sudden announcement to the public of the severe nature of the jusen problem and the need for taxpayer money to resolve the problem led to a major public outcry, however. Within an atmosphere of unprecedented political volatility accompanying the end of nearly 40 years of uninterrupted rule by the Liberal Democratic Party (LDP), and in the midst of economic recession, any request for the use of public funds was politically sensitive. The public's perception that regulatory breakdown had been spurred by collusion further heightened the political stakes. Numerous jusen had employed retired MOF bureaucrats on their boards, for example, revealing close ties with the ministry.

In an attempt to stem the public outcry, the three-party government coalition comprised of the LDP, Sakigake and Social Democratic parties stipulated that discussion of MOF reform would be a condition for debating the jusen resolution package in the Diet. For some time, the LDP managed to temper its coalition partners' demands for the actual removal of authority from the MOF. In October 1996, however, the LDP shifted its position to favour the transfer elsewhere of the MOF's inspection and supervisory authorities over private sector finance. With general elections approaching, the stakes were raised for appearing to be soft on the MOF.

In March 1997, bills to establish a new and independent financial regulatory agency were submitted to the Diet and, in June 1997, legislation providing for the creation of such an agency in 1998 was passed. In these ways, the environment of increased political volatility, combined with the revelation of regulatory breakdown and alleged collusion between the MOF and financial industry, gave rise to a change in formal regulatory structures. 


\section{The financial supervisory agency (FSA): independent but initially constrained}

On 22 June 1998, the Financial Supervisory Agency commenced business as an independent agency attached to the Prime Minister's Office and the remnants of the MOF's Banking and Securities Bureaus were merged into a single Financial System Planning Bureau (see Figure 2.1). The transfer of supervisory and inspection functions to the FSA was an important development. In addition to private sector finance, the MOF had overseen many other areas - notably budgetmaking and taxation - and had assumed the lead role in monetary and exchange rate policy. Bank inspections received very low institutional priority in the MOF and supervision of the sector was always carried out in the context of discussions about the economy as a whole. In contrast, the newly created FSA had a single mandate: to supervise financial institutions.

Yet, the agency was constrained in its ability to exploit this positive institutional development. These constraints were three-fold. First, in the absence of a credibly funded systematic scheme for dealing with bank failures, the FSA faced significant impediments to adopting a tougher stance toward banks. Judgments about asset values necessarily contain a subjective element, and any reversal of the MOF's overly optimistic judgments on the financial condition of banks would have plunged numerous institutions into insolvency. ${ }^{3}$ This, in turn, would have spurred panic and incurred the public's wrath rather than respect. The FSA was also required to consult with the MOF in cases in which the failure of a financial institution could potentially endanger the stability of the financial system as a whole. In the absence of an infrastructure for dealing with failing banks, falling bank shares and low market confidence, this meant consulting with the MOF in basically any decision to declare a financial institution insolvent. Decisions surrounding the use of deposit insurance funds also remained in the MOF's domain. And, since radically different asset assessments by the FSA would have suggested that the ministry had supported essentially insolvent institutions in the past, the FSA was further likely to encounter an uncooperative MOF. ${ }^{4}$

In the absence of a credibly funded scheme to deal with failing banks, the process of problem resolution necessarily remained particularistic and opaque. The pillar of solvency support methods had long been the 'rescue merger', in which the MOF arranged behind the scenes for a stronger banks to take over the operations of a weaker institution. Without an alternative arrangement in place, the MOF and the FSA worked in tandem to secure the 
Figure 2.1 Establishment of the financial supervisory agency (FSA) (22 June 1998)

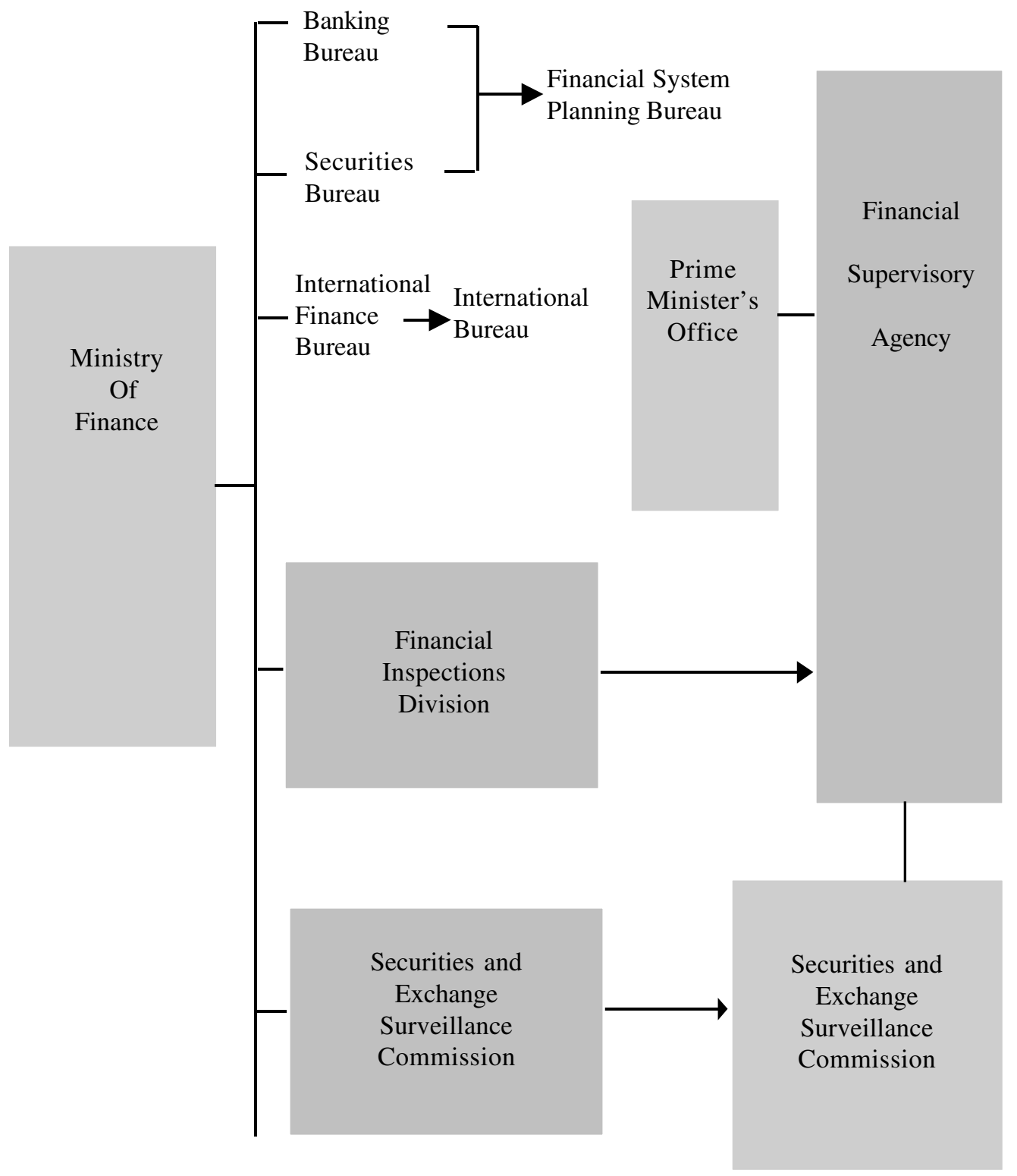


cooperation of other private sector actors in this quiet recapitalisation of ailing banks. In the process, the MOF and FSA continued to treat each bank's loan problems as a particular case, despite the pervasiveness of the problem throughout the sector.

Second, the new regulator lacked credible monitoring resources to back up the newly introduced Prompt Corrective Action (PCA) measures. The PCA program was included in legislation passed along with the jusen bail-out legislation in June 1996 but was not put into effect until April 1998 (for internationally active banks) and April 1999 (for domestic banks). For the first time, the program specified actions required by banks, and these were based on objective capital ratio standards. ${ }^{5}$ In this way, it was a scheme intended to narrow the band of discretionary authority accorded regulators. Yet, this program relied on banks to selfassess their assets. In the absence of both sufficient numbers of bank inspectors and expertise in such matters, the FSA could not credibly monitor banks to ensure compliance. Furthermore, the penalty for window dressing and inaccurate disclosure to authorities remained vague, decreasing the likelihood of compliance.

Third, the staffing of the FSA with large numbers of so-called noncareer officials led to a skewing of the incentive structures of individual bureaucrats. The hiring process for those MOF bureaucrats on this nonelite promotion track in the ministry differed considerably from the hiring of those bureaucrats staffing the top decision-making posts. Those who had staffed the Inspections Bureau in the MOF had been hired first into local Finance Bureaus after passing lower levels of the civil service examination, and had thereafter been promoted to the MOF central organisation. For these officials, job motivation was based largely on their affiliation with a ministry that was perceived to be at the peak of the bureaucratic hierarchy. Now, however, they were affiliated with an agency perceived as weak, only nominally independent and lacking in resources. In this way, demoralised staff were a large component of the new regulatory agency. ${ }^{6}$

In the above ways, then, change in formal regulatory structures alone failed to sever the informal ties between banks and regulatory authorities or eliminate the ad hoc institution of solvency support represented by 'rescue mergers'. Key elements necessary for a real shift to prudential regulation were missing. And, in the months following the FSA's creation, little deviation from past patterns of regulation or problem resolution was evident. Market perceptions of the financial soundness of major Japanese banks and confidence in Japanese regulators thus continued to deteriorate in the wake of this formal institutional change. 
Since the initial decision to establish the FSA, the financial system had fallen into a state of crisis. While the banking sector's nonperforming loan problem had been severe ever since the bursting of the speculative asset bubble in the early 1990s, their impact on the real economy only became clear in 1997. The failure of the nation's tenth largest bank and fourth largest securities firm in November 1997 pushed down the stock prices of all banks, thereby raising the costs of capital procurement for Japanese financial institutions in both the overseas and interbank markets. As a result, Japanese banks became cautious to an unprecedented degree in extending and rolling over loans to corporate clients, spurring a credit crunch. ${ }^{7}$

Stock prices continued to fall into 1998, further weakening banks - large shareholders themselves. Government actors were no longer able to fend off market forces due to the rising ratio of noncross-held shares and speculative attacks on fundamentally unsound financial institutions such as the Long Term Credit Bank (LTCB). Concern over the viability of the LTCB - whose stock values had plunged - was at a peak and both the MOF and FSA worked frantically behind the scenes to arrange a rescue merger. In September 1998, each agency proclaimed support for the LTCB's merger with Sumitomo Trust and Banking, a healthier bank that had come forward as a potential merger partner.

\section{From relational to rules-based regulation}

The pressures bearing upon the Japanese financial system and government actors in the fall of 1998 were such that some degree of change in the system of dealing with ailing banks was certain. The degree of regulatory reform and transparency introduced into the regulation of private sector finance in the October 1998 financial reforms was in no way inevitable, however. The key to the far-reaching changes lay in the opposition parties' capacity to seize control of the legislative agenda in the wake of the LDP's poor showing in the July 1998 Upper House elections on the backdrop of the deepening financial crisis. The LDP came up with a 'bridge bank' scheme intended to ensure the uninterrupted flow of funds to industry despite financial sector problems but the opposition rejected this proposal and succeeded in having its own legislative alternatives - formulated without consultation with the MOF - passed into law on 12 October.

The Financial Revitalisation Law and related bills established a new regulatory trajectory emphasising transparency and universally extending resolution methods. ${ }^{8}$ In the 
process, the package also severed the informal relational ties that had become so central yet problematic to more aggressive resolution of financial sector problems. There are four main ways in which these reforms effected a shift in the primary orientation of government authorities, from promoters and coordinators to monitors and prudential regulators of the financial system.

First, the reforms transformed the particularistic institution of solvency support represented by rescue mergers into a universal scheme for dealing with ailing financial institutions. The legislation passed in October 1998 at last established a credibly funded infrastructure for dealing with insolvent financial institutions of any size. Sixty trillion yen in public funds - an amount close to that of the annual government budget - was injected into the Deposit Insurance Corporation (DIC), enabling it to be used to support the temporary nationalisation of banks, the establishment of temporary bridge banks and the recapitalisation of banks nearing insolvency. ${ }^{9}$ As a result, the FSA was able to do its job without incurring systemic risk. ${ }^{10}$ Furthermore, with the universal scheme in place, the FSA was able to move forward and introduce stricter standards for asset assessment and loan loss reserve provisions without spurring panic among depositors. A necessary element in authorising the bankruptcies of the Long Term Credit and Nippon Credit banks in late 1998, for example, was the acknowledgment - for the first time - that their hidden losses on marketable securities constituted excessive levels of debt (Sasajima, Hasegawa and Fukushima 1999:7). In the aftermath of the reforms, the agency also heightened standards for loan write-offs from 2-3 per cent to 10 per cent. ${ }^{11}$

Second, the reforms brought about further change in the legal and institutional arrangements governing the financial system. The FSA's tougher stance on asset assessment was supported by legislative provisions that made disclosure of bad debts legally binding and stipulated that banks found to have intentionally covered up such information may be investigated for illegal activity on falsification charges. Although criminal charges of a breach of trust have only been brought so far against the top management of failed banks, this development alone is a notable break from the past. In less serious cases where falsification has not led to an institution's collapse, the FSA has tended to order the offending financial institution to clarify responsibility for the reporting of erroneous figures to the agency. The FSA has further required these financial institutions to take explicit steps to prevent a recurrence. ${ }^{12}$ 
Third, the Financial Revitalisation package enacted further changes in financial regulatory structures that served to empower the FSA. These changes included the establishment of a Financial Reconstruction Commission (FRC) to oversee the FSA and assume further responsibilities from the $\mathrm{MOF}$, as well as the creation of a cabinet position to oversee the commission (Figure 2.2). Sitting on the commission are an accountant, a former judge, a former Bank of Japan (BOJ) official and an executive from private industry. In contrast to earlier reforms, therefore, MOF authority was transferred this time to an entity that the ministry could not potentially 'colonise'. ${ }^{13}$ MOF officials sent to occupy top FSA posts received one-way tickets, never to return to the ministry.

The FRC assumed authority over decisions concerning the solvency of financial institutions from the FSA. Authority for decisions concerning the injection of funds into banks was also transferred to the FRC from the MOF. Decisions once entrusted to the Deposit Insurance Corporation (DIC) under the MOF umbrella were also transferred to the FRC. In line with the heavy responsibility accorded the commission, the law requires it to issue a public report on its activities twice a year.

The political leadership that the new cabinet post brought to the FSA has been critical to the agency's effective functioning since. In contrast to MOF officials who must deal closely with politicians in the annual budgetmaking process, FSA officials need not maintain close ties with politicians in order to carry out their work well. Nonetheless, having a minister devoted to agency representation in the Diet has been important for a number of reasons. It has given the agency a voice in the Diet - someone to speak out on its behalf when politically sensitive decisions - such as those to nationalise banks - are taken.

Political representation has also helped in the FSA's efforts to gain additional resources. The first Minister for Financial Reconstruction, Hakuo Yanagisawa, made a successful appeal for additional personnel resources in budget deliberations, for example. As a result, personnel numbers were increased substantially in FY1999 and are scheduled to increase further in FY2000 - even while numbers are being cut everywhere else in government. Furthermore, political leadership helped pave the way for the agency's hiring of individuals from failed private sector institutions and elsewhere - a clear departure from traditional civil service hiring procedures. This type of staffing, in turn, has enhanced the agency's expertise and credibility. ${ }^{14}$ Finally, the fact that a cabinet member heads the new regulator raises the agency's status to a level higher than other agencies attached to the Prime Minister's Office. ${ }^{15}$ 
Figure 2.2 Japan's new financial regulatory structure (23 October 1998)

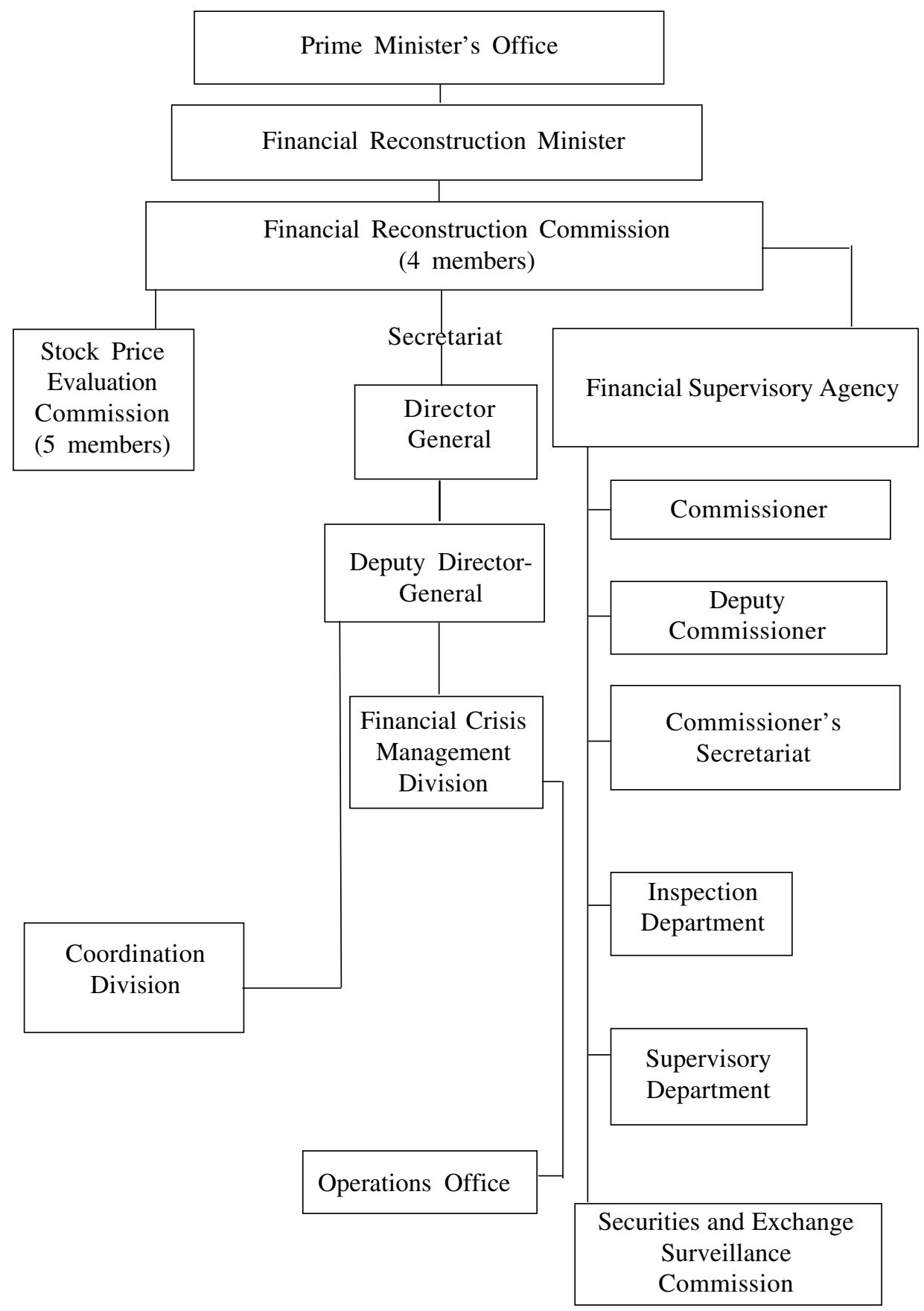

Source: Financial Supervisory Agency and Financial Reconstruction Commission. 
Finally, the Financial Revitalisation Law and related bills effectively eliminated the opaque ties between the MOF and banks. In the past, the ministry had been accused of allowing its officials to be wined and dined by so-called MOF-handlers (MOF-tan)in each bank and securities firm. Arrests of MOF officials in early 1998 on charges of accepting bribes had further undermined the credibility of Japanese financial regulators in the eyes of market players and the general public. The position of 'MOF-handler' no longer exists in private sector financial institutions. While individuals within banks are assigned to maintain contact with the MOF and FSA, such individuals no longer cultivate relationships with specific individuals in those agencies. Rather than meeting individually with private sector actors after hours, FSA officials now convene public forums for discussing key issues. ${ }^{16}$

The circumstances surrounding the FSA's development of a bank inspection manual illustrate the extent to which the interaction between regulators and private sector firms has changed. The establishment of a manual in April 1999 clarifying a classification system of borrowers and standards for loan-loss reserves and bad loan write-offs was a significant development, but even more noteworthy was the process through which it was developed. ${ }^{17}$ The introduction of the manual followed eight months of public discussions with banking sector officials - discussions that included the solicitation of public comments from various business organisations and individuals. Summaries of these discussions were placed on the FSA's Web site, available to the general public. In the past, the forum for discussion of an industry-wide issue such as this would have been nontransparent negotiations between the MOF and the Bankers' Federation.

Changes have also occurred in another aspect of informal ties linking regulators to private sector financial institutions: the hiring of former government officials - a practice referred to as amakudari or 'descent from heaven'. The additional personnel costs incurred by banks through such appointments run counter to the cost-cutting measures banks are being pressured to undertake by the FSA. With the abandonment of the government's implicit guarantee of no bank failures, the benefits of maintaining such relations have also largely disappeared. The decisions to nationalise Nippon Credit Bank (NCB) and the LTCB were particularly notable developments symbolising the severing of such entrenched informal ties between financial regulators and private sector financial institutions. These two institutions long served as depositories for high-ranking MOF retirees and upon their nationalisation, criminal charges of breach of trust were brought against former MOF officials on their boards. ${ }^{18}$ 
Now that the FSA is empowered to act decisively and follow up inspections with appropriate supervision, its officials can take pride in being at the centre of the financial sector cleanup. The Japanese media has lauded the FSA's strengthened supervision and the resulting public perception of regulatory competence boosts depositor confidence in banks that pass agency inspection. This fact is important, in light of the planned lifting of the ceiling on deposit insurance in 2002.

Banks must now change organisational conventions to complement the new regulatory framework. This necessarily includes clarifying management responsibility, and restructuring. Japanese banks have historically been top-heavy, with boards of directors made up of as many as 50 or 60 members - few of whom were cognisant of major bank decisions. ${ }^{19}$ The FSA has required banks to clarify which individuals assume final responsibility for bank decisions and has urged reductions in the numbers of managing directors. Restructuring so as to boost profitability remains a major challenge, however, and the success of government-level changes depends heavily on improvement in the banks' bottom line. The repayment of public funds received in 1998 and 1999 will require better profit performance. The return of these funds, in turn, remains politically important.

In brief, the arrangements for prudential regulation of Japanese financial markets have changed dramatically. The FSA's motto of 'rule-based supervision' (horitsu ni shitagatte kantoku suru) contrasts with the relations-based supervision observed in the MOF where regulatory outcomes were determined more through a process of negotiation. And, decisions coming out of the FSA provide evidence in support of this shift. After five decades of coddling the sector, Japan's regulators placed two of the nation's largest banks under temporary government control in late 1998 and declared five smaller regional banks insolvent in 1999, taking them into government receivership. Furthermore, for the first time, bank shareholders were forced to take losses. The unprecedented level of participation of foreign financial institutions in the Japanese financial sector serves as further testimony to the heightened prudential regulatory standards, clearly articulated rules and transparent administration ushered in by the Financial Revitalisation Law and related bills. ${ }^{20}$

\section{Implications for patterns of policymaking interaction}

As the above discussion has noted, major outcomes of recent financial reforms include the shift from relational to rules-based regulation and the devolution of areas formerly under the 
MOF's authority to other agencies. Let us now consider the impact of these changes in financial regulatory processes on more general patterns of policymaking interaction involving the MOF and on other finance-related areas such as fiscal and monetary policymaking.

The ability of the MOF to persist for so long in its use of informal relational ties as a forum for problem resolution and regulation in Japanese finance was due largely to the insulation of the domestic financial sector. This enabling condition broke down progressively from the 1980s onwards, and the very informal nature of coordination between the MOF and banks proved inimical to the internationalisation of Japanese financial markets. The international market increasingly demanded information, transparency and accountability.

International market forces have not penetrated all areas of Japanese finance equally, however. The MOF retains authority over fiscal policymaking and informal ties continue to play a central role here. As the holder of the nation's purse strings, the MOF maintains close relations with the Diet. Accordingly, there are more former MOF officials elected to the Diet than former officials from any other government agency, and this pattern has been seen throughout the postwar period. Furthermore, MOF officials on temporary assignment continue to occupy positions in the legislation bureaus and standing committee offices of both houses, where Diet members are assisted with drafting bills. MOF officials regularly take up positions in the Prime Minister's Office, Cabinet, Minister's Secretariat and Cabinet Legislative Bureau. As in the past, these points of regular contact give the ministry numerous points at which it can gather intelligence helpful in gauging the receptivity of elected officials to policy proposals and gives the ministry numerous opportunities to influence the policymaking process once legislation enters the Diet. This is particularly important in regard to budget and tax legislation, which must gain passage in the Diet annually.

There is little evidence that heightened transparency in the area of financial regulation has translated into heightened transparency in the MOF's interagency relations or in negotiations between the MOF and elected officials. ${ }^{21}$ The ministry's continued control of the budget means that relations between the MOF and other agencies remain hierarchical in nature and personnel flows between the MOF and other agencies are distinctly dense. ${ }^{22}$ As another reflection of the continued power that the holding of the nation's purse strings brings, amakudari flows between the MOF and the so-called public finance corporations remain strong. ${ }^{23}$ And, while flows of former MOF officials into private sector financial institutions have significantly decreased, these officials continue to be in strong demand in private sector corporations in other sectors of the economy, as well as in industry associations. ${ }^{24}$ 
In these ways, the shift away from relationally based policymaking and implementation has not encompassed the entire ministry. And, given that it is in the most powerful bureaus (Budget and Tax) that opaque relational ties remain alive and well, there is a danger that movement toward greater transparency in private sector finance may be impinged upon by the persistent opacity of policymaking in public finance. Although the MOF's authority over the inspection and supervision of private sector finance was transferred to the FSA and the FRC, the ministry retains control over the areas of financial system policymaking and exchange rate policies with its Financial System Planning and International Bureaus.

Tensions between policymaking exigencies are perhaps most strong between the International Bureau and the fiscal policy bureaus of Budget and Tax. For the international faction in the MOF, transparency is the key to international competitiveness and pressure for such transparency prevails from the international market and through gaiatsu or foreign pressure. Thus, the International Bureau priorities transparency (toumeisei). In contrast, the domestically focused bureaus of Budget and Tax priorities and focus on interministerial adjustment and negotiation (kanchokan chosei). Even with the passage of information disclosure laws, little transparency is likely to emerge in the process of interministerial negotiations. Disclosure of details surrounding the final outcomes of policy decisions and the official government rationale may be more forthcoming than in the past, but there is little evidence to suggest that there will be disclosure of the process of interministerial adjustment and coordination underlying those policy outputs.

Ties between MOF bureaucrats and Diet members may, in general, be less institutionally embedded and more pluralistic, however. In the past, a clear norm existed within the MOF that politicians were not to be brought in to participate in intraministerial debates. The standard operating procedure was to resolve conflict and dissent on a particular issue within the ministry and then present a united front to outside actors on the issue. More reformminded MOF bureaucrats, however, have disregarded this principle in recent years, and have linked up with politicians to push their financial system reform agendas (Otake 1999). ${ }^{25}$ In doing so, these individuals effectively introduced some degree of transparency into the process, with the aim of drawing on the leverage of public opinion to achieve policy goals. In this respect, pluralism within the ministry is being brought more into the open, just as recent partisan realignment has increasingly brought political conflict and debate out of the backrooms and into the public arena of Diet debate. 
The MOF's ties with the Bank of Japan have also altered considerably in recent years. The new Bank of Japan Act that came into effect on 1 April 1998 devolved responsibility for monetary policy to the central bank. In the past, tradition dictated that the BOJ governor alternated between a career BOJ official and a former MOF administrative vice-minister (AVM). The staffing of the top BOJ post by a former MOF AVM was problematic - not only in terms of MOF influence on BOJ policy but also in terms of political influence on the central bank. This was because every MOF AVM was well versed in annual budget negotiations with politicians and was necessarily very political. The tradition of staffing the BOJ governorship with former MOF officials is unlikely to continue. Today the BOJ, under the leadership of an individual with both private sector and central bank experience, displays much greater independence from the MOF than in the past. ${ }^{26}$ Amid concerns over the high yen in late September 1999, for example, central banks officials clearly rejected the expressed desires of MOF officials to carry out additional monetary relaxation.

Accountability, accessibility, transparency and fairness are all characteristics of the new financial regulatory regime that deal with process. These attributes are not direct indicators of broader outcomes, however - even though they have become more important indicators in the present era of financial liberalisation where markets reward opacity with suspicion. Heightened transparency in the policymaking process does not necessarily equate with greater policymaking efficiency. And, the more fragmented nature of Japanese financial authorities today arguably decreases the efficiency of policy coordination within the government.

In the past, a single institution - the MOF - dealt with ailing financial institutions and the injection of public funds. Today, three institutions - the MOF, the FSA and the FRC - each have a hand in this process. The result is two-fold: more time-consuming communication and coordination among authorities and a decision-making process more removed from direct MOF influence.

Although the MOF was long referred to as kyoku atte sho nashi or as being more like a collection of bureaus than a coherent agency, these bureaus were nonetheless under the same roof in the past and led by the same cabinet minister. Final decisions concerning financial policies were made through negotiation between the MOF Secretariat (Daijin Kanbo) and the finance minister, with the MOF Secretariat holding a great deal of authority in such negotiations (Author interview with official in FRC Secretariat 1999). Today, in contrast, final decisions are made through negotiations between two cabinet ministers - the finance 
minister and the minister for financial reconstruction. In this way, final decisions are more removed from the influence of career MOF bureaucrats. In cases when the two cabinet ministers have had differences of opinions on policy issues, this mode of decision making has also been more time-consuming (Author interview with official in FRC Secretariat, 1999).

The committee structure of the FRC also means that decision making in this organisation differs significantly from that mode formerly found in the MOF. Decision making in the FRC takes place in committee meetings and career bureaucrats working on policy issues must obtain the understanding of the four committee members and the minister for financial reconstruction. One MOF official seconded to the FRC Secretariat stated: 'The burden of explanation is heavier in the FRC than it was in the MOF, where all officials had similar backgrounds, thus making it unnecessary in most cases to explain minute details. With the FRC, everything must be thoroughly (tettei-teki ni) explained' (Author interview with official in FRC Secretariat 1999). The nature of the FRC committee meetings also differs significantly from other government-related committee meetings such as deliberation councils or shingikai that bring experts from diverse backgrounds together. This is because each FRC member feels that he must personally accept final responsibility and therefore final decisions fail to move forward in the presence of any single member's dissent. In contrast, a final report is usually issued from shingikai even if all members' opinions are not entirely reconciled. ${ }^{27}$ While this process of decision making in the FRC suggests greater transparency and accountability, it also suggests a more time-consuming process.

\section{Conclusion}

The decisive actions taken by Japan's Financial Supervisory Agency (FSA) since October 1998 contrast sharply with the MOF's previous eight years of policy paralysis and delay in addressing the banking system's huge nonperforming loan problem. These actions also contrast sharply with the FSA's own regulatory behaviour in its first four months of existence, thus illustrating the limited impact of changes only at the level of formal institutional structures. This paper has argued that the difference observed from October 1998 onward can be traced to the shift from relations-based to rules-based regulation effected by the Financial Revitalisation Law and related bills. This package of legislation severed the web of informal relational ties that had long been central to financial regulation and thereby introduced transparency into the regulatory process. 
The ripple effects of this shift from relations-based to rules-based financial regulation are reverberating throughout the Japanese economy. Tightened regulatory standards and government pressure on banks to dispose of their large sums of nonperforming loans have forced Japanese banks to place greater emphasis on profits. This, in turn, is straining main bank relationships and diluting cross shareholding ties between banks and borrowers. Bank tie-ups across longstanding keiretsu lines are further eroding the lines of demarcation of traditional business groups, and thereby changing the way corporations operate and obtain financing. ${ }^{28}$ By underpinning the system with adequate prudential regulation and supervision, the FSA has set the stage for liberalisation under the Big Bang reforms to bring its promised benefits.

While the reforms effected in October 1998 - including the establishment of the FRC, nationalisation and bridge bank schemes, and fund injections - were intended as temporary measures lasting through 2001, the changes embodied by the June 1998 creation of the FSA are more permanent. In July 2000, however, the FSA will absorb the MOF's Financial Planning Bureau and be renamed the Kinyucho or Finance Agency (see Figure 2.3). ${ }^{29}$ Functions

Figure 2.3 Planned changes in the financial regulatory structure (July 2000)

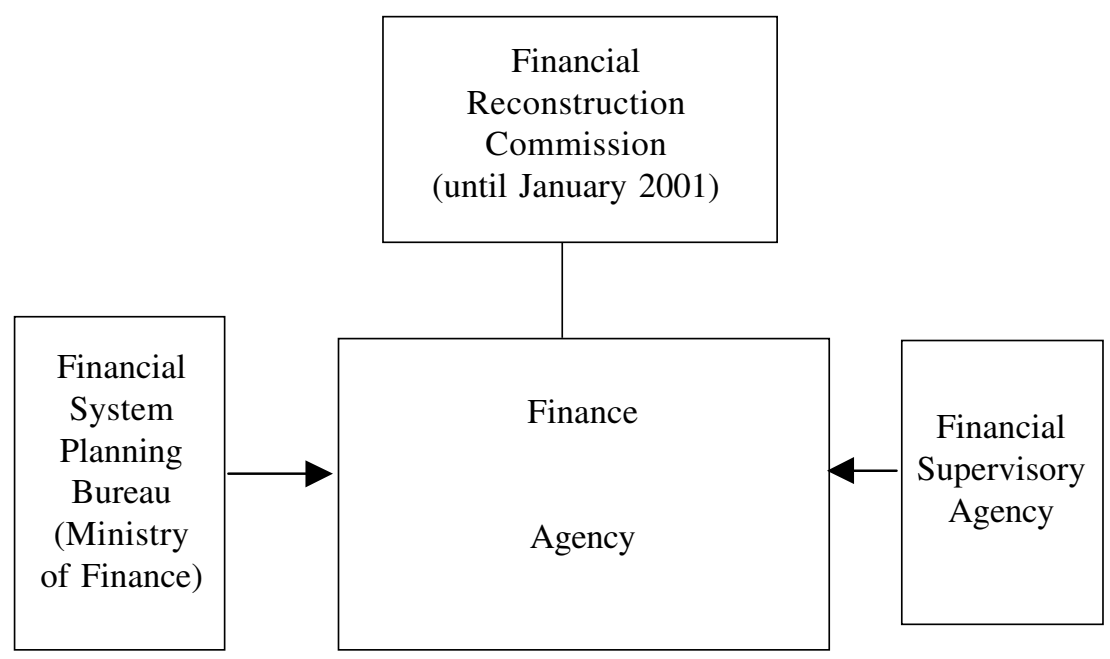


currently carried out by the FRC will then be transferred to the new Finance Agency in January 2001, when a larger reorganisation of the central government is set to take place. ${ }^{30}$

Japan's economic and financial problems are clearly not over. Private sector capital investment and consumer demand have not yet taken over from government spending as the impetus for growth. Furthermore, the Diet's recent decision to delay the reintroduction of the ceiling on deposit insurance protection represents a disappointing step backward in the area of financial system reform. Nonetheless, the evidence of the past 18 months points to a dramatic shift in the primary orientation of the nation's regulatory authorities from promoters and coordinators to monitors and prudential regulators of the financial sector.

\section{Notes}

1 The law's full name is the Law Concerning Emergency Measures for the Revitalisation of Function to the Financial System (Kinyu kino saisei kinkyu sochi ho).

2 Notably, however, the issue did generate debate within the ministry and some in the Financial Inspections Division were opposed to this judgement.

3 Had the FSA made such reversals in decisions upon its establishment in June 1998, numerous banks would have gone into insolvency without a scheme in place for managing the problem. Thus, prior to the October 1998 financial reforms, exercising the option to change assessment criteria would have merely spurred panic and incurred the public's wrath.

4 Bureaucracies have a tendency to resist reversals in institutional judgments, for doing so draws criticism - not only of those making the change in judgement but also of those who exercised lenient judgments at an earlier time. The flow of former MOF bureaucrats into private sector financial institutions (amakudari) upon retirement exacerbated the inherent inertia in the MOF. Former ministry officials in positions in private sector banks would be affected negatively by stricter regulatory standards; yet, such individuals played a role in deciding the amakudari postings of more junior colleagues still in the ministry. Thus, implicating one's former boss could have a direct bearing on one's own future.

5 The Prompt Correction Action measures were modelled after a similar program introduced by US regulatory authorities in 1991.

6 The media's scepticism of the new regulatory agency and allegations that the shift of regulatory authority to the FSA was merely a case of kanban nurikai or switching of the signboards further undermined the agency's credibility.

$7 \quad$ Major financial institutions that collapsed in this period included Sanyo Securities, Hokkaido Takushoku Bank and Yamaichi Securities. 
The second package of government-proposed legislation that followed in the Diet later in the same month was also clearly important in stabilizing the financial system. These bills dealt with the recapitalisation of relatively healthy banks. Nonetheless, the effectiveness of this legislation was greatly enhanced by its implementation under the new rules of the game, established by the Financial Revitalisation Law and related bills.

9 The DIC was established in 1971 but had been inadequately funded. Funds were insufficient to cover the failure of even a regional bank. Under the new scheme, regulators have three possible routes. First, the FRC can sends in receivers to assess the condition of assets and find another institution willing to take over the ailing bank once its condition is clarified. Second, in the case that there is no willing candidate to absorb the problem bank, the failing institution becomes a bridge bank and credit continues to be extended to sound borrowers until a receiving bank is found to assume its business and customers. Third, the FRC can temporarily nationalize a bank (either through the bank's request or forcibly). In the case of temporary nationalisation, the government takes all ordinary shares and the Stock Price Evaluation Committee under the umbrella of the FRC determines the price at which shares are purchased, based on its appraisal of the value of good assets held by the problem bank. This committee, initially numbering five but increased to six in May 1999, is comprised of two university professors, one lawyer, two certified public accountants and a manufacturing company executive. No career government officials are involved in making judgments concerning stock prices.

10 From 15 December 1998, the newly established Financial Reconstruction Commission (FRC) has made decisions concerning the solvency of financial institutions but from the October passage of the Financial Revitalisation Bill until this date, the FSA assumed authority for such decisions. It was during the FSA's period of responsibility that the Long Term Credit Bank (LTCB) and Nippon Credit Bank (NCB) were nationalised.

11 This shift may be interpreted as more than an acknowledgement of changed conditions. The shift may also be seen as an institutional defence strategy: adoption of stricter criteria avoided future criticism of the agency.

12 For example, in February 2000, the FSA ordered the Daihyaku Mutual Life Insurance Company to clarify management responsibility for the erroneous reporting of its solvency margin ratio to authorities and to take steps to ensure the disguising of its loans does not happen again.

13 Approximately half (19) of the 37 individuals staffing the FRC Secretariat, however, were on loan from the MOF.

14 Individuals from those institutions know well the methods of hiding bad assets.

15 The Fair Trade Commission (FTC), for example, has long been criticised for its lack of clout and independence, and its lack of political leadership is often cited as a factor in this.

16 In March 1998 - even prior to the FSA's commencement of business - the MOF announced the creation of 'impartial and transparent forums' for exchanging information between the ministry and financial sector actors (Nikkei Net Interactive 'MOF, Financial Institutions to Exchange Info Via New Panels', at <http:// 
www.nni.nikkei.co.jp/AC/FEAT/failures/failures00263.html>, accessed on 17 April 2000). This move was in response to a string of bribery scandals involving MOF officials and suggesting collusive relations between the MOF and individual financial institutions. The use today of public forums is not only in contrast to the practice of exchanging information after hours over drinking and eating. It is also in contrast to the heavy reliance in the past by the MOF on the chair of the Federation of Bankers' Associations in Japan (Zenginkyo) as the mouthpiece of the industry. The chair of the Zenginkyo rotated every year among the presidents of the Tokyo Bankers' Association. In any given year, however, the other banks felt disadvantaged in their dealings with the MOF, as the process of interaction between MOF officials and the federation chair was highly opaque and the MOF's discretionary power vast. The MOF-liaison position in banks thus evolved largely in response to this monopolisation of information by the Zenginkyo chair. The FSA has opened up most issues to discussion in public forums, however, and proceedings are now transparent to all banks in the industry.

17 With the manual, inspection standards were clarified for the first time - thereby eliminating the frequent past practice of administrative guidance.

18 Although the amakudari link between private sector financial institutions and the MOF has changed drastically in the last two years, banks still hire many former bureaucrats from other agencies. Officials from the Police Agency, for example, are often hired to assist banks in dealing with the sokaiya (racketeers disrupting shareholding meetings) and yakuza (those in the crime world involved in such activities as money laundering).

19 In March 1998, for example, 61 individuals served as directors at the Bank of TokyoMitsubishi (BOT-M). Although unusually large in number, the size of BOT-M's board reflected a long-standing problem created by bank mergers in Japan: the inflation of executive ranks and obscuring of any locus of accountability or responsibility due to the desire to avoid conflict among merging entities.

20 Extensive deregulation under the Big Bang financial reforms has, of course, also played an important role in spurring this trend. Yet, it is unlikely that foreign actors would have entered the Japanese financial market with such zeal if the credibility of regulators and suspicions about collusion had remained unabated. In September 1999, it was announced that the Aoba Life Insurance Company would be sold to a French holding company, marking the first sale of a failed Japanese financial institution to a foreign company. The sale of the nationalised Long Term Credit Bank (LTCB) to an American-based consortium of financial institutions was announced soon after and was finalised in March 2000.

21 This could change, however, as public attention turns increasingly to fiscal reconstruction and areas of public finance - such as public works spending - fall under greater scrutiny.

22 Furthermore, although the MOF has lost regulatory capacity over private sector finance, it retains policymaking capacities. Thus, the ministry remains the key decision maker behind the ongoing financial system reforms. 
23 For example, MOF's former administrative vice-minister was named the first governor of the institution created through a merger of the Japan Development Bank and the Hokkaido Development Corporation.

24 In 1999 the number of former MOF officials taking up private sector posts outnumbered those from any other ministry or agency, at 12 (National Personnel Authority 1999). Aggregate numbers of amakudari postings from the bureaucracy into the private sector have declined, however.

25 The former vice-minister for international affairs, Eisuke Sakakibara, is one example of such an individual.

26 Ironically, because the BOJ no longer has a role in management of bank failures, its influence on private sector finance has diminished. In the past, even more former BOJ officials took up posts in private sector banks than did former MOF officials. Under the new Bank of Japan Law, BOJ officials are no longer permitted to assume management positions in private sector banks upon retirement from the central bank.

27 Because the burden of individual responsibility weighs less heavily in shingikai, dissenting members generally do not object too much (Author interviews with central government bureaucrats, 1999).

28 Major Japanese trading companies, for example, have accelerated debt reduction operations and other restructuring of assets, citing rising demands from creditors for loan repayment and the change in business environment and customer relations brought about by the merger of leading banks. See 'Trading Houses Feel Restructuring Heat', The Nikkei Weekly, at <http:www.nikkei.co.jp/AC/TNW/Nni20000117M Q0K2FIN. htm>.

29 In April 2000, responsibility for supervision of credit cooperatives was handed over to the FSA from municipal governments. The FSA also faces the prospect of gaining more regulatory influence over the agricultural credit cooperative system in the near future. The FSA and the MAFF have shared responsibility for supervision of agricultural cooperatives, but the FSA's responsibility lies with inspection and supervision of the Norinchukin Bank, the agricultural sector's central bank, while the MAFF's responsibility lies with supervision and inspection of the prefectural and local-level agricultural cooperatives. Current plans to integrate prefectural federations of cooperatives with Norinchukin Bank, therefore - if realised - will increase the FSA's regulatory influence in the agricultural credit cooperative system, where consolidation has thus far lagged far behind that in the commercial banking industry.

30 This larger reorganisation involves consolidating the current 23 ministries and agencies into 13. 
Pacific Economic Papers

\section{References}

Financial Reconstruction Commission Web site <www.frc.go.jp >.

Financial Supervisory Agency Web site <www.fsa.go.jp >.

Ministry of Finance Web site <www.mof.go.jp>.

National Personnel Authority (1999) Amakudari White Paper, Government of Japan, Tokyo.

Nikkei Net Interactive, accessed on various dates.

The Nikkei Weekly, various issues.

Otake, Hideo (1999) Nihon Seiji no Tairitsujiku, Chuko Shinsho, Tokyo.

Sasajima, K., K. Hasegawa and A. Fukushima (1999) 'Japanese Banking Sector', Warburg Dillon Read Research Report, 2 February. 


\title{
Freer D iscussion of Predetermined Agendas: Reform and Continuity in Japan's Shingi kai Deliberation Councils
}

\author{
G regory N oble
}

Australian $\mathrm{N}$ ational $\mathrm{U}$ niversity 



\section{CONTENTS}

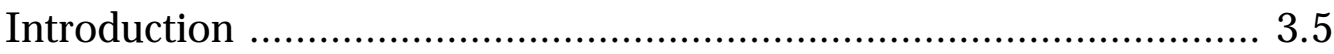

I mpetus and proposals for reform ................................................. 3.7

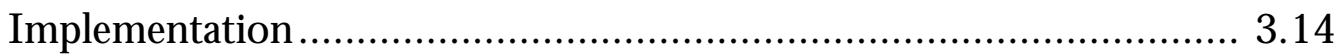

Shingikai in action: electricity regulation and broadcasting ................ 3.16

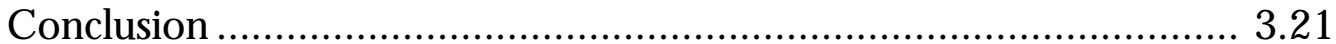

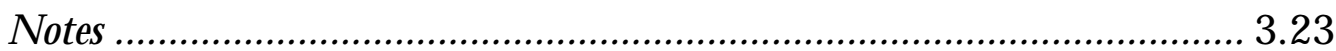

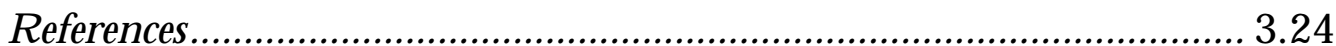





\section{Freer Discussion of Predetermined Agendas: Reform and Continuity in JAPAN's SHINGIKAI Deliberation Councils}

\section{Introduction}

Over the past several years the movement to increase transparency in government and reduce bureaucratic influence over policymaking appears to have gathered considerable momentum in Japan. The Diet has passed laws on administrative procedures and information openness while a Cabinet resolution has mandated the establishment of a public comment system throughout the Japanese administration. In the (northern) summer of 1999, the Diet finally passed a series of bills to reorganise the entire system of central ministries and strengthen control over policymaking by the Diet and Cabinet.

Amidst all the changes, efforts have also taken aim at the organisation and operation of Japan's elaborate system of shingikai or deliberation councils. Deliberative bodies designed to provide private-sector input to official decision making are hardly unique to Japan, but in few - if any - countries are they as ubiquitous, stable and closely tied to the central departments of government (Schwartz 1998). An official survey in 1998 counted more than 450 shingikai and the related but less formal kondankai (discussion councils) (Management and Coordination Agency 1998a). Major shingikai explore policies for industrial structure, financial and tax systems, social security and local government and other central concerns of government. Narrower panels consider such issues as auto racing, livestock promotion and female juvenile delinquents (Management and Coordination Agency 1998a).

The push to reform shingikai is surprising, even ironic. Many observers, particularly abroad, have expressed deep admiration for the networks of communication between government and business in Japan epitomised by the shingikai. Hilton Root, for example, writes 'deliberative councils ... can provide a framework for the cooperation of economic actors by limiting the government's ability to change policy arbitrarily and, hence, redistribute economic rents and wealth' (Root 1998:69). In Japan and other East Asian countries, Root argues: 


\section{Pacific Economic Papers}

The council format facilitated bargains between constituent groups in exchange for information needed to formulate rational economic policies. The exchanges helped leadership evaluate policy performance and ensure policy-makers accurate information about private sector assets and strategies. These council formats also facilitated, with varying degrees of success, the sharing of information between firms about markets, marketing strategies, products and new technology...Intervention [by governments in markets] tended to succeed in nations that had effective frameworks for the exchange of information between state and society. The East Asian governments that are conventionally viewed as authoritarian feature a high level of consensus building and are particularly effective at reducing information asymmetries in the economic policy dialogue. (Root 1998:69-70,72)

Sociologist Peter Evans further praises deliberation councils and other informal networks for enabling Japanese ministries and agencies to develop a form of 'embedded autonomy'. Meritocratic appointments and long career paths help agencies maintain autonomy and avoid corruption, while deliberation councils and other networks enable their officials to exchange information freely with the private sector (Evans 1995:49). Even economists such as Komiya Ryutaro - who gained fame for his biting criticisms of the interventionist policies of the Ministry of International Trade and Industry - have highlighted the contributions of shingikai. Komiya concluded that 'whatever the defects in the postwar Japanese approach to industrial policy, [shingikai] have been a very effective means for the collection, exchange and dissemination of information on industry and as such have contributed greatly to postwar economic growth' (Komiya 1988:19). ${ }^{1}$ The World Bank's well-known East Asian Miracle study (partly funded by the Japanese government) also singles out deliberation councils for approbation (World Bank 1993:181-2).

Despite this praise from economists, sociologists, international financial institutions and consultants, shingikai have come in for withering attacks from specialists in Japanese politics and administration. Shingikai, they charge, lack openness and accountability. Outsiders are unable to participate or monitor council proceedings. Opaque procedures shield discussion and conflict. Deliberation councils preempt debate in the Diet and other public fora.

Most observers blame the bureaucrats for this sad state of affairs. Japanese ministries, critics charge, use shingikai as 'magic cloaks of invisibility' (kakuremino) to obscure the reality of bureaucratic control. Elite bureaucrats set the agendas, select the personnel - often 
former officials of the ministry itself - and draft the reports. A close observer of a major shingikai, the Financial System Research Council of the Ministry of Finance (MOF), noted that the council is 'convened, sponsored, and guided by officials of the [MOF]. As a result, it generally functions as a mechanism for legitimising proposals from the ministry itself'. As the chair of another Finance Ministry advisory council remarked, 'the biggest problem is that the bureaucrats ultimately steer these various investigatory councils; no matter how many opinions are aired, the debate invariably moves in the direction the bureaucrats think is right' (Hartcher 1998:247-8). ${ }^{2}$ Other critics note that shingikai often serve as a site for rigai chosei (interest coordination) among private firms. In this role the shingikai may facilitate the manipulation of government policy to increase barriers to entry by would-be competitors, and thereby support the maintenance of cartels. Still others lay primary blame for fostering and manipulating the shingikai to serve insider interests on the zoku (tribe) of politicians in Japan's governing Liberal Democratic Party (LDP) who are constantly on the hunt for particularistic benefits to hand to their constituents and campaign contributors. Most analysts pool together bureaucrats, business interests and backbench politicians as vested interests - three sides in Japan's version of iron triangles. Where the World Bank sees cooperation and communication, these critics discern exclusion and collusion.

The movement to reform the shingikai system faces deeply entrenched resistance and raises two important questions. Have the reforms moved shingikai closer to the ideal held by foreigners, retaining the advantages of information interchange while creating an open style of communication less amenable to bureaucratic control? And what does the fate of the reforms suggest about broader trends in Japanese administration and politics?

\section{Impetus and proposals for reform}

The movement to reform shingikai is embedded in larger criticisms of the Japanese bureaucratic system. The call to 'administrative reform' dates back at least to 1924 when the pioneering journalist Ishibashi Tanzan (who was to serve a brief stint as prime minister in the 1950s) argued that 'bureaucratic rule is only a temporary aberration of a revolutionary era. Now ... bureaucrats should return to their role as public servants'(Nakano 1998:299). The first formal administrative reform council emerged in the early 1960s but had little effect. ${ }^{3}$ Beginning in 1981, the more ambitious second reform council (daini rincho) succeeded in privatising three major public corporations. On most other issues its proposals foundered in 


\section{Pacific Economic Papers}

the face of stiff opposition, but its 1983 report did include a call to strive for greater transparency in the operation of shingikai (Nogami 1997:251).

Administrative reform received a boost from the weakening of LDP rule and the fraying of close relations between the LDP and the bureaucracy, beginning with the LDP's loss of a majority in the Upper House in 1989 and accelerating dramatically after the party's temporary fall from power in 1993-94. The LDP believed that bureaucrats had cooperated too readily with the parties in the non-LDP coalition. They also sensed that the public had turned against the bureaucracy, following a series of corruption scandals and policy setbacks (Mishima 1998:982). Events tarnishing the image and reputation of government agencies included a belated response to the massive 1995 Kobe earthquake, the Ministry of Health and Welfare's failure to protect the public against AIDS-tainted blood, and the Ministry of Finance's inability to prevent the collapse of several leading banks and securities firms in 1997. The economic stagnation that had dogged the first half of the 1990s seemed about to lift in 1997 when the Ministry of Finance inadvisably increased the consumption tax, nipping the recovery in the bud and further eroding public confidence in the ability of the bureaucracy to guide the economy.

Support for administrative reform emanated from several sources. General popular support was an important background factor, but relatively passive and sporadic. Political parties were also ambivalent. Prime Minister Hosokawa, who broke away from the LDP and formed the first non-LDP government in decades, advocated administrative reform but lacked political heft and fell victim to a campaign finance scandal. As prime minister from 1996 to 1998, the LDP's Hashimoto Ryutaro pledged his political life to reform, but took a relatively narrow, technocratic approach to reform that stressed efficiency more than openness. A former zoku leader himself, he was often unable to overcome resistance from zoku politicians in his own party (Nakano 1998).

More consistent support came from three sources. Academics (particularly economists but also some professors of law), administrators and politicians provided intellectual backing for administrative reform, proselytised for the cause and served on many advisory councils. Keidanren, the leading business organisation, also acted as a persistent and far-reaching advocate of reforms to reduce expenditures and increase efficiency and transparency. For at least a decade, observers have portrayed Keidanren as declining in unity and influence, but on broad issues such as taxes, labour and administrative reform it has proved itself relatively unified and potent (Noble 1998:fn 82, 211). Within Keidanren, an Administrative Reform 
Group continuously monitored, advocated and publicised initiatives to increase transparency. Not surprisingly, Keidanren perceived the bureaucracy - rather than entrenched private firms and their political supporters - to be the major obstacle to administrative reform. Yet Keidanren consistently pushed measures that stood to undermine the privileged position of some of its members in the hopes of creating a freer and more competitive environment for business as a whole (Author interviews, Administrative Reform Group, Keidanren, 11 June 1999). ${ }^{4}$ Finally, within the bureaucracy, the Management and Coordination Agency (MCA) assumed an important role as promoter and monitor of administrative reform. When the prime minister or Cabinet issued orders to carry out various reforms, the MCA assumed responsibility for implementation. Though the MCA traditionally did not enjoy a reputation as a strong agency, the institutional role of overseer gave it a rationale for intervening in the affairs of other ministries, just as MOF's control of the budget has allowed it to influence a wide range of policies. Like Keidanren, the MCA has the personnel to provide the expertise and institutional continuity that politicians, citizens groups and academics interested in administrative reform often lack.

The administrative reform movement first began to exert a noticeable if still modest impact on the organisation of shingikai at the end of 1991. A committee coordinating the policies of the central agencies reached an accord that shingikai should make available to the public transcripts of their deliberations, interim and final reports and petitions addressed to them (Management and Coordination Agency 1991). Only in cases where such disclosure significantly impeded fair and balanced discussion or created inappropriate disadvantages or advantages for specific parties would this principle be excepted.

A similar interministerial committee took a further step in mid-1994 under pressure from non-LDP forces led by Prime Minister Hata Tsutomu, former Prime Minister Hosokawa and especially the New Party Sakigake. Sakigake emerged as a group of young former LDP representatives who opposed zoku politics and emphasised that administrative reform should not limit itself to attainment of a 'small and efficient government' but should strive to create a more open and accountable system of governance as well (Nakano 1998). The Hata Cabinet passed the guidelines the day before it resigned. In addition to repeating the earlier, but often ignored, injunction to provide transcripts and reports, the new guidelines called for 'fair and balanced representation' in selecting members for shingikai and provision of public hearings to allow those affected by deliberation council decisions to present their opinions. While slightly more extensive, these guidelines were still far from revolutionary. The 


\section{Pacific Economic Papers}

interministerial committee emphasised that the guidelines did not replace previous resolutions and were not meant to impinge upon the autonomous operations of councils (Management and Coordination Agency 1994).

Much more aggressive guidelines emerged a little more than a year later in the form of a Cabinet Resolution. Pushed by Sakigake, now a minor partner in an odd coalition government dominated by the LDP and its erstwhile enemy the Social Democratic Party of Japan (formerly known as the Japan Socialist Party), the resolution ordered ministries and agencies to:

(1) Avoid the creation of new shingikai whenever possible. Instead, promote the development of officials with necessary specialised knowledge, hold public hearings and solicit opinions of related organisations.

(2) Review, before the end of the fiscal year, the necessity of shingikai in existence for more than ten years or those which have not named new members within the last five years.

(3) Set deadlines for shingikai established to address special and temporary (rinji) issues.

(4) Eliminate reduplication, if necessary, by creating subcommittees.

(5) Eliminate participation of retired officials, advisers and other former officials of ministries, particularly as committee chairs.

(6) Make transcripts (gijiroku) and minutes or summaries (giji youshi) available for reproduction by average users in hard copy form, databases or computer on-line systems, or provide a formal written explanation of why proceedings are not open.

Although the resolution contained a sharper critique and more specific requirements, it also contained two potential loopholes. First, critics noted, it drew a distinction between general (ippan no) shingikai established to discuss policy and special bodies dedicated to dealing with specific and sensitive administrative matters such as personnel issues and petitions by particular parties against administrative decisions. Only the former were (in principle) required to make public their proceedings (Nogami 1997:253). A second point attracted less attention but provided greater space for potential abuse. The resolution drew a distinction between shingikai and kondankai, a looser term denoting discussion groups or even social gatherings. Kondankai differed from shingikai, the resolution claimed, because they simply provided a site ( $b a$ ) for discussion and exchange of ideas on specific administrative operations (gyosei un'ei jou no kaigou) rather than broad policy issues. As a result, the resolution only 
enjoined ministries to 'strive to assure transparency' in operations along the lines laid out for shingikai. In the wake of this resolution, the MCA began, for the first time, to conduct and publish detailed surveys on compliance by shingikai with the principles laid out between 1991 and 1995.

The harshest and most sustained criticism of shingikai came in the July 1996 interim report of the Subcommittee for Demarcation of Public and Private Sector Activities, one of three subcommittees of the Administrative Reform Committee (gyosei kaikaku iinkai; the other two subcommittees covered information disclosure and deregulation) (Secretariat for the Committee on Administrative Reform 1997). Six economists and four business executives dominated the subcommittee's membership of thirteen. Not surprisingly, the subcommittee's interim report displayed a distinctly Anglo-Saxon orientation: administrative intervention is permissible only in presence of market failures and even then only reluctantly, for strictly limited time periods, and with due recognition of the possibility of (greater) government failure. The interim report called for introducing market principles and explicit cost-benefit analysis wherever possible, application of bond market discipline and recourse to judicial appeal, as well as promotion of disclosure and accountability.

The subcommittee levelled a raft of harsh criticisms at shingikai, repeating the claim that they serve as 'magic cloaks' for agencies and perpetuate bureaucratic sectionalism (tatewari gyosei). To the familiar list of suggestions about balance, openness and efficiency made by previous panels and Cabinet resolutions, it added a number of bolder or more specific suggestions:

(1) replace shingikai with public hearings, Diet debates and referenda wherever possible;

(2) reduce reduplication and overall numbers of deliberation councils;

(3) widen membership; focus on genuine experts; include more consumers ('seikatsu-sha'), women and labour representatives;

(4) eliminate direct conflicts of interest;

(5) publicise dissenting opinions; and

(6) strengthen administrative function and keep bureaucrats completely away from the drafting of reports.

The one exception to this barrage of criticism involved shingikai working on administrative reform, which naturally was presented as valuable. While the subcommittee claimed to 


\section{Pacific Economic Papers}

represent the public against vested interests, like the other reports on the topic of administrative reform it violated its own principles by not discussing costs and benefits, disclosing conflicts of opinion, or presenting alternative options for the prime minister, the Diet and society to consider. And, of course bureaucrats - in this case officials of the Management and Coordination Agency - were intimately involved in the subcommittee's activities, as they were in all the shingikai of the administrative reform movement.

The subcommittee soon retreated from the lofty heights of economic theory, however. Shortly after issuing its interim report, the subcommittee held hearings with the ministries. In October 1996 a new election strengthened the position of the LDP. By the time the full committee released its report to the Prime Minister in mid-December, the discussion of shingikai had shrunk to two short and general paragraphs in background materials. The paragraphs noted the problems of sectionalism and bureaucratic control and vaguely suggested (kento suru koto mo kangaerareru) greater use of alternatives such as hearings and referenda (Secretariat for the Committee on Administrative Reform:54). All discussion of shingikai reform disappeared from the formal report.

The retreat in tone from the subcommittee's report to the final report of the full committee reflected a broader counterattack by zoku politicians, their constituents and powerful ministries against Hashimoto's overall plans for bold reform. Many authors have seized on this as evidence that particularistic politics has yet again triumphed in Japan. ${ }^{5}$ Surprisingly, though, the attempt to reform shingikai did not end with Hashimoto's retreat. By 1999 Hashimoto's successor, the deceptively amiable and modest LDP veteran Obuchi Keizo succeeded in passing a new law on information openness, and in pushing through the first major reorganisation of the Japanese ministries in many decades. While Obuchi's plans, too, came under attack for having caved in to resistance from bureaucrats and vested interests on some important issues, they did not by any means completely abandon the attempt to reassert political leadership and to increase governmental accountability. The laws on ministerial reorganisation included a detailed section on reform of shingikai (Government of Japan 1999). ${ }^{6}$ While less ideological and scathing in its criticisms than the July 1996 Interim Report of the Administrative Reform Committee's Demarcation Subcommittee, the new resolution was in some ways even more pointed. In addition to repeating earlier calls to rationalise and reduce the number of shingikai, provide material to the public on shingikai operations, severely restrict appointment of ex-ministry officials and so forth, it introduced a number of new and more specific requirements on both membership and operations: 
(1) reduce membership to 20 or fewer if possible or no more than 30 if necessary;

(2) avoid appointment of politicians, bureaucrats and old people;

(3) limit representatives of 'one side' to one half or less of total membership;

(4) increase the proportion of women to 30 per cent within 10 years;

(5) limit members to simultaneous participation in no more than three shingikai;

(6) limit individual terms to two years or shorter and a total of ten years or less after the reorganisation of the bureaucracy; and

avoid imposing unanimity on reports and include any dissenting views.

As with previous resolutions, the 1999 guidelines contained a couple of potential loopholes. First, they allowed officials to establish informal kondankai. These kondankai were to avoid creation of permanent rules of order and any implication that they were proffering 'conclusions' or 'opinions'. It was even unacceptable to say that a kondankai had been 'established'; rather, agencies should speak of kondankai as 'meeting'. The danger was that provisions intended to emphasise the informal and nonbinding character of consultative discussion might actually provide a quasi-secret refuge from the new standards on openness for discussions that might be as serious and high level as in the old shingikai. Second, the guidelines enjoined shingikai from creating their own administrative organs; instead, they were to rely on existing administrative agencies. While aimed at blocking the accretion of bureaucracy, in practice the regulations seem likely to favour the existing ministries and agencies since they retained independent administrative capacities that the new and reformed shingikai would be forbidden to match.

Finally, for the first time the government announced specific plans to eliminate or downgrade many shingikai. Under the plan drafted by the MCA, the total number of shingikai would fall by more than half. Deliberation councils related to 'basic policy' would fall to 22 , including such influential bodies as MITI's Industrial Structure Council and the telecommunications shingikai of the Ministry of Posts and Telecommunications (MPT). Councils aimed at implementation of laws and regulations would decrease to 42, including MPT's postal shingikai and the shingikai on local finances. Some councils would be allowed to run until their current mandates expired while others would move to the Cabinet and lose their status as formal shingikai. The MCA targeted 121 councils for outright elimination, including such bastions of particularistic politics as the shingikai that set prices for rice and milk, adjust 


\section{Pacific Economic Papers}

interest rates and promote the textile industry. Only four new shingikai would be added - all of them related to the MCA and administrative reform.

\section{Implementation}

For all these bold proposals, the important question is whether deliberative councils have actually altered their ways since criticism and orders to reform began to accelerate in the mid1990s. Annual surveys conducted by the MCA from 1996 to 1998 (the most recent year for which data are available) provide the most comprehensive overview (Management and Coordination Agency 1998a), while supplementary information on specific shingikai updates and adds some detail to the picture.

The surveys reveal both continuity and change. Almost all councils publicised their creation, purpose, schedule and list of topics, as well as members and their current affiliations (although not whether they were former officials of the sponsoring ministry or agency) - but most had done so for years. As of 1998, admittedly before release of the more specific suggestions for elimination of redundant deliberation councils, the MCA's figures showed little change in overall numbers. Shingikai still numbered 212-220, while the average number of participants remained at just over 24 per council, well over the recommended new maximums. Some important signs of change emerge in the figures for participation. Before the Cabinet resolution on former officials, former ministry officials accounted for a full onethird of shingikai chairs, according to a special MCA survey in May 1995. In 1997 and 1998 the percentage of councils chaired by former officials declined dramatically, first to 9.6 per cent and then to 3.4 per cent. The average percentage of ex-officials per council dropped from 9.6 per cent in 1995 to 7.0 per cent in 1998 (302 of the total of 4,330 members). Only four ministries (Foreign Affairs, Agriculture, Transportation and Finance) topped 10 per cent and even then only barely. Foreign Affairs led the list at 12.0 per cent while MITI just missed the mark at 9.8 per cent. Sixty-four of the 152 relevant councils - including most of the major councils for MOF, MITI and the MPT - provided hearings in which those affected by deliberations would be able to air their concerns. The MCA provided no figures for the degree of participation by those representing 'one side' of the deliberations, probably because the proposal was not formalised until 1999; although even had it tried the agency might have found it conceptually difficult to provide such a count. 
Some additional - if partial - information suggests that changes in the composition and chairing of panels are real and continuing. Interviews conducted at MITI the same day that the Administrative Reform Committee tendered its report to Prime Minister Hashimoto (16 December 1996) revealed that ministry officials were concerned to reorient the membership of the Industrial Structure Council to expand the representation of emerging firms and decrease that of declining industries. MITI researchers have also expressed an interest in increasing the voice of new software companies relative to the established producers of electronic hardware (Kuroki and Kato 1994:196-212). Similar changes were visible at the Economic Planning Agency. In early 1999 the agency appointed members to five advisory councils. The newly reconstituted panels were half the size of their predecessors and included three Japanese-speaking foreigners as well as representatives of small, local and new companies. Among the new members was the vice-president of start-up company Hokkaido Airlines, which had recently cut prices on tickets from Tokyo to Sapporo, Hokkaido's leading city, to half the levels maintained by the old oligopoly of the three incumbent airlines (Nikkei Weekly, 15 February 1999).

Finally, some indications suggested that ministries found it increasingly difficult to achieve the appointment of ex-ministry officials to stack the advisory system in their favour. The MPT's postal shingikai, for instance, had long supported the ministry in trying to block the efforts of the administrative reform movement to privatise the postal system. When the panel's chair, a professor from Keio University, retired at the end of 1997, the ministry dragged its heels in naming a new chair, claiming that conflicts within the committee made it difficult to attain consensus. As a result, the panel fell under the leadership of the acting chair, an MPT 'old boy'. This outcome led to bad publicity and public dissatisfaction. In June 1998 MPT announced the new chair - the head of Matsushita Electric (Nihon Keizai Shinbun, 13 February 1998 and 5 June 1998). Apparently, the recommendation of the administrative reform movement that former officials should not serve as chairs of advisory councils had assumed the status of a new norm.

Data on openness also show significant progress. In 1996 only half the shingikai either held open meetings or released transcripts; that figure increased to 68.4 per cent in 1997 and 73.0 per cent in 1998 (when 28 per cent did both). Of the remainder, all but one shingikai released minutes or summaries; the exception was a Ministry of Foreign Affairs committee that cited the need to protect diplomatic secrets. Observers were divided on whether summaries, which typically did not identify positions with their articulators, were sufficient 


\section{Pacific Economic Papers}

and desirable. Some argued that only open meetings or transcripts provided the public with a full sense of the debates and positions of members. Others countered that preserving a free atmosphere promoted the frank exchange of opinions (not to mention the practical and theoretical difficulties of publishing an accurate transcript of open-ended and often free-form discussions) (Abe 1997:194-5). At any rate, by 1998 over two-thirds of shingikai provided transcripts of their proceedings, compared to just under half (49.3 per cent) in 1996. Twothirds of the councils (102) posted information on their activities in data bases or Web sites. Many provided intermediate reports (29), opportunities for public comments (33), final press conferences (38), or other methods to disseminate information to public, including seminars and pamphlets (25).

Although the general trend to openness has been strong, differences across ministries remain significant. In 1998, for example, a majority of MITI's shingikai both held open meetings and released transcripts of their proceedings, while none of the Finance Ministry's shingikai did so, limiting themselves to disseminating the minutes. Interestingly, the two main administrative reform councils (gyosei kaikaku iinkai and gyosei kaikaku kaigi) cited 'protecting free discussion' as the reason for releasing only minutes (one subcommittee, on central-local relations, did provide transcripts).

The survey results released by the MCA provide evidence that the informal kondankai are less open than shingikai, but they too are improving. There is as yet no clear evidence that ministries are surreptitiously moving discussions to kondankai to circumvent the increasingly stringent rules on transparency applied to shingikai, although the possibility remains and would certainly be consistent with Japan's historical preference for the informal. As suggested in the documents prepared by the administrative reform movement and endorsed by the Diet, kondankai tend to be more specialised and ad hoc than shingikai. ${ }^{7}$

Measures on openness released by the MCA showed some improvement. In 1996 only 19.0 per cent of kondankai either opened their meetings, published full transcripts, or both; by 1998 that figure had increased to 30.3 per cent. Almost 90 per cent ( 89.4 per cent) at least published minutes, including 25 kondankai attached to MPT, 11 under MITI's jurisdiction and 5 organised by the MOF.

\section{Shingikai in action: electricity regulation and broadcasting}

The vast array of subjects deliberated by shingikai and kondankai, and the immense volume of the reports they release, render efforts to generalise about the transparency of their 
operations both difficult and hazardous. According to officials at the MCA, the ministry whose treatment of shingikai is the most open and advanced is MITI; among the other more advanced ministries is MPT, particularly in telecommunications and broadcasting (rather than postal affairs) (Author interview, MCA Administrative Management Bureau, 9 June 1999). Examination of shingikai reports and interviews with participants conducted for research into the comparative dynamics of deregulation in Japan (rapid in the case of broadcasting, carefully measured in electricity regulation) can provide insight into the possibilities for change. Study of the use of shingikai in these cases thus constitutes hypothesis generation rather than hypothesis testing: if change is not observable in the shingikai associated with MITI and MPT (outside postal affairs), then it is not likely to be found in construction, finance or agriculture. If significant change is found, more extensive research is justified.

While such client industries of MITI as automobiles, electronics and machine tools sell significant proportions of their output on global markets and thus are highly attentive to competitive pressures, the electricity sector has long had a protected, comfortable and very large market niche. Throughout the postwar period, Japan's 10 electric power companies enjoyed virtual monopolies on power generation within their geographically determined districts. MITI protected and regulated the utilities. They in turn cooperated with MITI, investing during recessions, devoting $R \& D$ expenditures to pollution control and alternative fuels, and building nuclear power plants to reduce Japan's dependence on imported oil. Electric utilities became a prime example of Richard Samuels' noted proposition that governance in Japan is a process of 'reciprocal consent' in which private companies accept government intervention in return for support and stability (Samuels 1987).

In the 1990s the economic and technological premises of this cosy relationship came under increasing pressure. The successful move to competition in the telecommunications industry, combined with developments in technology that reduced economies of scale in electricity generation, suggested that it might not be necessary to view electricity as a natural monopoly. Extended recession and the growing strength of the yen created pressures to reduce Japan's 'high cost structure', including electricity rates that significantly exceeded those of Japan's main competitors. Concern grew especially intense when the exchange rate approached 80 yen to the dollar in 1995. By early 1997 conflict between MITI and its erstwhile prize client became intense. On behalf of the overall Japanese economy, MITI demanded rate cuts; in response the utilities pointed to MITI's own long-standing goals in Japan's energy 
policy, such as energy security, environmental protection, and universal service and stability of supply. Years of heavy investment rendered the utilities financially weak, but many of them exerted great economic and political influence in their districts. To up the ante, MITI implemented a 'yardstick' system that rewarded the more efficient utilities with favourable rates and even threatened to break up the electricity utilities as a way of introducing market incentives. The utilities fought back by accusing MITI of contravening the injunction of the administrative reform movement to reduce administrative interference in the operations of private firms (Nikkei Weekly, 27 January 1997 and 17 February 1997). ${ }^{8}$

MITI and the Administrative Reform Committee agreed on the need to reduce the 'high cost structure' and they succeeding in getting the Cabinet to include resolutions pushing for more competition and lower rates. The Cabinet resolution of December 1996 ordered MITI's electric utility shingikai to find ways to bring Japan's utility rates down to the level of other advanced industrial countries by 2001 . The MCA met with MITI and other relevant agencies, while the LDP's Headquarters for the Promotion of Administrative Reform presented its own report to the Cabinet in March 1997. In May the Cabinet passed a resolution endorsing an action plan which incorporated their suggestions virtually in toto.

Once it had gained the support of the Administrative Reform Committee, the LDP and the Cabinet, MITI announced specific policy proposals. MITI created within the electric utility shingikai a new subcommittee on basic policies and for the first time in several years reopened the subcommittee on the rate structure. ${ }^{9}$ The committee members selected by MITI represented a balance among professors, journalists and other neutral figures; utilities; and independent power providers (IPPs). The IPPs were comprised primarily of trading companies or heavy industrial providers such as petrochemical or paper companies that hoped to generate more of their own power and perhaps sell back a bit to the electric utilities. The IPPS received as many seats as the electric utilities, even though they generated less than 2 per cent of Japan's electricity. MITI prepared a model of complete liberalisation - the greatest fear of the utility monopolies - and elicited named responses from four of the members. Three of them were academic economists while the other was the representative director of the AsiaPacific Energy Forum. While MITI's report was scrupulously balanced in presenting the theoretical and practical advantages and disadvantages attendant upon complete liberalisation, the very form of presentation involved an open admission of pluralistic goals, options and opinions that was previously rare in shingikai (Electric Utilities Publications 1999a:199252). In January 1999 the subcommittee reached a compromise involving partial liberalisa- 
tion for large users, the introduction of competitive bidding for thermal plants, and enhanced flexibility to reduce rates. The measures were fairly conservative compared with electricity deregulation in other countries, but there was little question that MITI utilised the shingikai system to stack the deck in its favour and put extra pressure on the formidable electric utilities.

Once the subcommittee had finished its report, MITI pushed ahead again. Even before passage of the public comments law, it invited public responses to the subcommittee's report. Among the 59 responses, many of them quite detailed, were representations from the United States Trade Representative calling for further liberalisation, and four complaints about the lack of transparency and balance in selecting members, who were seen as too close to the industry (Electric Utilities Publications 1999a). Since MITI's goal was to pressure the utilities to move faster, these comments were useful. MITI's responses to the comments showed little willingness to incorporate other ideas that would change the ministry's agenda. Indeed, some industry observers characterised the ministry's 'we've already considered that' style of reply as arrogant (Author interviews with industry actors, Tokyo, June 1999). Next, MITI selected new members to the subcommittees. Building upon the rationales about avoiding conflicts of interest advanced by the administrative reform movement, it removed all industry representatives, both utility and IPP, from the electric utility shingikai, relegating them to three slots as 'observers'. MITI's bold step shocked and concerned the industry (Gekkan Enerugi, June 1999: 42-3). With the industry representatives removed, the council's membership consisted of 11 economics professors, who favoured MITI's aggressive approach (if not more so). According to people who have attended the meetings, the industry observers were by no means completely isolated. They only had to raise their hands to be recognised by the chair. Nonetheless, MITI's control over the agenda and membership of the committee allowed it to reduce the relative influence of the industry, particularly the electric utilities (Author interviews, Central Research Institute for the Electric Power Industry (CRIEPI), 10 June 1999).

Even more than in electricity, the legal framework surrounding television broadcasting required the regulator (the Ministry of Posts and Telecommunications), to channel virtually all policy issues through shingikai, while the ministry routinely created kondankai to deliberate on ad hoc issues. For decades, the relationship between MPT and the broadcasting industry was stable and profitable for all. By the end of the 1980s that stable relationship came under pressure (Noble 2000). As with electricity regulations, the example of dynamic 


\section{Pacific Economic Papers}

changes in telecommunications policy cast a long shadow, as did even greater technological changes. A virtual revolution in digital compression and satellite transponders effectively reduced the scarcity of the electromagnetic spectrum, loosening the traditional rationale for regulation of broadcasting. MPT shingikai were forced to deliberate a host of new issues, including the allocation of licenses on satellites, digital broadcasting formats, the speed of digitalisation of signals from conventional terrestrial stations, and the number of channels any one company should be permitted to control. Encumbered by its traditional clients, MPT initially responded cautiously and at times ineffectively to technological change, leaving it vulnerable to increasing pressure from MITI, its long-time rival for control of policy for the increasingly merged field of telecommunications and computing.

A similar pattern of bureaucratic reformulation of shingikai to prod reluctant clients is observable in the regulation of television broadcasting. The MPT stacked some deliberative bodies with professors and, like EPA, began to incorporate some Westerners representing new interests. Shingikai meetings remained closed and the ministry cited concern for protecting corporate secrets and free discussion as justifications for not releasing full transcripts, but it placed detailed minutes of deliberations going back to 1996 on the Internet. Particularly interesting was MPT's changing approach to the handling of conflict. Through the early 1990s MPT's shingikai reports blandly muffled conflicting opinions. ${ }^{10}$ In the mid1990 s, as the Ministry strove to update policy and the administrative reform movement affected expectations about shingikai operations, reports became much more open. A 1995 panel on the influence of multimedia on broadcasting not only admitted a split within the committee over when to shift to digitalisation of broadcasting satellites, but also identified the members of the opposing camps within the committee by name (Ministry of Posts and Telecommunications 1995). The next year the final report of the kondankai on the upgrading of broadcasting detailed the reactions of various groups to the interim report (Ministry of Posts and Telecommunications 1996). ${ }^{11}$ In 1997 a deliberative council composed only of academics produced a report on digitalisation that frankly revealed conflicting stances. It reported the results of a survey revealing the existence of a variety of opinions in the industry, and reproduced a long appendix presenting the opinions of each firm or organisation surveyed by the committee (BS-4 Kohatsuki Kentokai 1997). It appears that the degree to which conflict is aired reflects strategic manipulation by MPT. The ministry may stack the deck in its favour by picking only scholars for councils that are intended to challenge existing producers, by issuing unanimous reports when they agree with its preferences and allowing conflict to 
surface when it cannot bring the majority, particularly existing producers, along to its side. As ministries face an increasing strain between the attainment of their organisational missions and the wish to protect old clients, the traditional preference for consensus over transparency seems to be breaking down.

In addition to writing specific reports, many of MPT's shingikai regularly meet to discuss current issues faced by the ministry. An examination of a recent meeting of the Radio Regulatory Commission (Denpa Shingikai) (No. 825, July 16, 1999, released 31 August 1999) provides some insight into current practices. ${ }^{12}$ Following usual practice, the meeting was held in the ministry's headquarters rather than an independent or neutral site. Four of the five members attended the meeting: three professors (of law, media communications and engineering) and the president of Kansai Electric. They conferred with at least as many MPT officials. The group discussed a number of issues, some of them legally or technologically complex, including the appropriate number of licenses for FM stations in Niigata prefecture and technical results of tests on 720-line progressive digital signals and whether they qualify as high definition. MPT officials started off with presentations to which the council members addressed questions. Judging from the minutes, the issues excited little controversy. The discussion consisted largely of presentations by MPT officials and answers by MPT to questions, some of them rather elementary, from the council. The meetings, though detailed, did not link specific individuals with questions or answers. The entire meeting lasted 67 minutes. MPT released the minutes after a delay of six weeks.

\section{Conclusion}

Despite the widespread scepticism about administrative reform, persistent efforts to increase transparency have begun to exert a measurable impact on the operation of Japan's deliberative councils. The selection of members is now more open and balanced. Participation by former officials of ministries and agencies has declined dramatically. New legislation mandates the regular incorporation of public comments on proposed administrative actions and shingikai deliberations. Meetings and reports are more open and more readily available.

Who wins and who loses from the increase in transparency? The expanded availability of information and the broadening of participation beyond narrow circles of industry insiders benefit the mass public, increase the ease of access by would-be new entrants and facilitate political debate. These reforms were major goals of administrative reform, and to a surprising extent they have been attained. 


\section{Pacific Economic Papers}

A second, more broadly political, goal of administrative reform was to wrest control of policymaking from the bureaucracy. Results to date suggest, however, that efforts to increase transparency - at least in the area of shingikai - have not only failed to humble the bureaucracy, but actually have helped to strengthen its position. The bureaucracy retains most of the key prerogatives. It still sets the agenda for deliberation, names the participants, handles administrative arrangements, drafts reports and replies to public comments. While incumbent firms are somewhat checked by the new arrangements, the bureaucracy has gained wider latitude to manipulate the expression of conflict for its own purposes. Ministries can selectively stack the deck with reformist academics when they want changes and maintain a significant industry presence when they want to deflect or slow suggestions for change. Ministries can modulate the degree of disunity reflected in shingikai reports. Limits on appointments of former officials - ostensibly a major blow against the bureaucracy actually may be at least as much of an advantage as a restriction, particularly when a ministry wants to challenge industry. Former officials, after all, represent both the ministry at which they served in the past and the industry interests for which they work at present. ${ }^{13}$

The transparency movement has thus energised ministries, enabling them selectively to break loose from clients when their desire for maintenance of the status quo interferes with attainment of the ministries' organisational missions. 'Iron triangles', after all, are both a support for and a constraint upon bureaucrats. If industry and its allied zoku supporters in the Diet do not provide iron-clad political support, the ministry might be better off dumping them and pursuing an aggressive promotional agenda of its own setting. The three major areas regulated by MPT provide an illuminating example of the alternative possibilities. Zoku politicians have been extraordinarily supportive of the 'three postal services' (posts plus the banking and insurance products offered by post offices in Japan). MPT has thus been able to resist with near impunity pressures from the Keidanren and the administrative reform movement to privatise the three postal services. Broadcasting, in contrast, elicits much less support from backbench politicians. It is also subjective to greater technological and economic pressures for change. The more MPT resists those pressures the more antediluvian it looks - for no discernible payback. Telecommunications rests between postal services and broadcasting: more politically powerful and slightly less revolutionised by technology. Not surprisingly, MPT shingikai support the status quo on postal services, articulate the case for slow but steady reform of telecommunications and aggressively push for changes in broadcasting even at the expense of the existing producers. 
Hartcher (1998) notes an interesting variant in the financial sector. The Ministry of Finance has traditionally allied itself with existing banks, securities houses and insurance firms (and, notably, against the postal banking and insurance operations). Its secretive shingikai have represented and supported the status quo. However, financial scandals have stained the reputation of the ministry and demonstrated that Japan's traditional 'convoy' approach to regulation is increasingly inadequate to deal with changes in the global financial system. Accordingly, many in the MOF have come to argue that the ministry should abandon financial regulation to concentrate on its core missions: compiling budgets and overseeing monetary policy (Hartcher 1998:24-41; 255-6).

The bureaucracy's ability to emerge stronger than ever from waves of attempted reform has inspired much gnashing of teeth in Japan. Genuine reform, it seems, to many Japanese, is doomed. ${ }^{14}$ But if we conceive of the problem not as constraining scheming bureaucrats but as weakening Japan's notoriously closed and particularistic style of policymaking, freeing bureaucrats to articulate a broader vision to get out of Japan's current morass may actually offer some advantages. ${ }^{15}$ Analysts agree that political parties are not yet ready to take the lead in policy reform in a more consistent way, although that could change with the reorganisation of the central bureaucracy and possibly, an election or two down the road, the reorganisation of the party system (Nakano 1998; Vogel 1999). At that point the Japanese people can put their votes where their complaints are. Till then, freer discussion of agendas set by the bureaucrats may be their best chance to influence policymaking.

\section{Notes}

1 Komiya eventually accepted a position as head of MITI's economics research institute.

2 The complaint came from Kato Hiroshi, chair of the Tax Committee, quoted in Tokyo Business Today 63:10 (October 1995).

3 For a review of successive efforts at administrative review, see Nogami (1997). A useful timeline appears in Matsubara (1999:228-32).

4 See Keidanren (1998).

5 See, for example, the works cited above by Nakano, Mishima, Nogami and Matsubara.

6 Later passed in mid-June 1999 as part of the ministerial reorganisation plan. 


\section{Pacific Economic Papers}

7 The names of two kondankai, the MPT's 'Research group on systems for the realisation of (telephone and fax) number portability' and the Science and Technology Agency's 'Evaluation committee on analysis of radioactivity' are illustrative of this greater specificity. Nonetheless, the breadth of policy focus of some kondankai appeared to differ imperceptibly from those of shingikai. Examples of such more broadly focused kondankai included the Economic Planning Agency's 'Research group on foreign aid policies', the MOF's 'Kondankai on new trends in finance' or the MPT's 'Kondankai to consider the fusion of telecommunications and broadcasting'.

8 Also, author interviews at the Central Research Institute for the Electric Power Industry (CRIEPI), 9 April 1998 and 10 June 1999; MITI Energy and Natural Resources Agency, April 8, 1998 and Tokyo Electric Power Company, December 1996.

$9 \quad$ Shingikai reports, Cabinet resolutions, industry statistics and other useful materials are collected in Electric Utilities Publications (1999a and 1999b).

10 For a major example, see Ministry of Posts and Telecommunications (1992).

11 The report did not, however, link firms and organizations with specific stands.

12 See <www.mpt.go.jp/policyreports/japanese/radio/90831j01.html>, accessed 10 September 1999; affiliations from Management and Coordination Agency (1998b:437).

13 By the late 1990s the whole system of amakudari appointments (placement of former bureaucrats into private sector posts) came under withering public scrutiny. Thus, the sustainability of this system was already under question.

14 In addition to the citations above, see the following article by an indignant and frustrated Takushoku University professor (Tanaka 12 June 1999:62-3).

15 Thus, I largely concur with the analysis of Japan's predicament articulated by Mishima (1998), but writing a year later and with attention to the specific problem of shingikai, I find slightly more grounds for optimism.

\section{References}

Abe, Yoshitaka (1997) Joho kokai (Information Openness), Nihon Hyoronsha, Tokyo.

BS-4 Kohatsuki Kentokai (eds) (1997) BS hoso no digitaru-ka ni mukete (Toward Digitalization of Broadcasting by Broadcasting Satellites), Kurieito Kuruzu, Tokyo.

Electric Utilities Publications (1999a) Denryoku kouzoukaikaku, kyoukyuu shisutemu-hen (Reform of the Structure of Electric Power: the supply system), Electric Utilities, Tokyo.

Electric Utilities Publications (1999b) Denryoku kouzoukaikaku, ryokin seido-hen (Reform of the Structure of Electric Power: the rate system), Electric Utilities, Tokyo.

Evans, Peter (1995) Embedded Autonomy: States and Industrial Transformation, Princeton University Press, Princeton.

Gekkan Enerugi (Energy Monthly) 32:6 (June 1996). 
Government of Japan (1999) 'Shingikai no Seiri Gorika ni kansuru kihon teki keikaku' (Basic plan regarding the rationalization and reorganization of shingikai and other deliberative councils) in Chuo shouchou tou kaikaku suishin honbu kettei, 'Chuo shocho tou kaikaku no suishin ni kansuru houshin'(Guiding principles on promotion of reform of central agencies), Tokyo, 27 April.

Hartcher, Peter (1998) The Ministry: The Inside Story of Japan's Ministry of Finance, HarperCollins, London.

Keidanren 1998, 'For the promotion of deregulation aimed at economic revival and the establishment of a transparent system of governmental management - basic thinking', Tokyo, 20 October.

Mishima, Ko (1998) 'The changing relationship between Japan's LDP and the bureaucracy: Hashimoto's administrative reform effort and its politics', Asian Survey 38:10, pp. 968-85.

Komiya, Ryutaro (1988) 'Introduction' in R. Komiya, M. Okuno and K. Suzumura, Industrial Policy of Japan, Academic Press, San Diego.

Kuroki, Akihiro and Akira Kato (1994) 'Shinki gijutsu no hyojun-ka: denki, denshi kiki ni okeru kesu stadi' (Standardization in new technology areas: a case study of electric and electronic equipment) Tsusan Kenkyu Rebyu (MITI Research Review) 3, pp. 196212.

Management and Coordination Agency (1991), Gyosei jyoho koho kijun ni tsuite (On Standards for the Openness of Administrative Information), Tokyo, 11 December.

Management Coordination Agency (1994) Shingikai-tou gaidorain sakutei no tame no kankei shocho renraku kaigi moshiawase, shingikai-tou oyobi kondankai-tou gyosei un'ei-jo no kaigou no un'eitou ni kansuru shishin' (Guidelines on the Operation of Meetings and other Aspects of Shingikai and Other Deliberative Councils, and Kondankai and other Meetings on Administrative Operations), Tokyo, 24 June.

Management and Coordination Agency (1998a), 'Shingikai-to no kokai-to no suishin jokyo ni kansuru foroappu chosa kekka' (The Results of a Follow-up Survey on the Promotion of Information Openness and other Reforms for Shingikai and other Deliberative Councils), Administrative Management Bureau, Tokyo, 20 March.

Management and Coordination Agency (1998b) Shingikai Soran, Heisei 10 nenban (Almanac of Deliberation Councils), Tokyo.

Matsubara, Satoru (1999) Nihon risutora: gyoukaku koso saisei no kirifude (Restructuring Japan: Administrative Reform is the Trump Card to Resuscitation), Tokyo Shoseki, Tokyo.

Ministry of Posts and Telecommunications (1992) Hoso no shorai tenbo (Future Prospects for Broadcasting), Gyosei, Tokyo.

Ministry of Posts and Telecommunications (1995) 'Maruchi media jidai ni muketa hoso no tenbo: hoso ga chukaku-teki medi a to shite hatten suru tame ni' (Prospects for broadcasting as it faces the multi-media age: Let broadcasting develop into a core medium), Final report, 29 March.

Ministry of Posts and Telecommunications (1996) 'Hoso kodo-ka bijion' (A vision of the upgrading of broadcasting), Advisory report to the director of the Broadcasting Division, Tokyo, 26 June. 


\section{Pacific Economic Papers}

Nakano, Koichi (1998) 'The politics of administrative reform in Japan, 1993-1998: toward a more accountable government?' Asian Survey 38:3, pp. 291-309.

Noble, Gregory W. (1998) Collective Action in East Asia: How Ruling Parties Shape Industrial Policy, Cornell University Press, Ithaca.

Noble, Gregory W. (2000) 'Let a hundred channels contend: technological change, political opening and bureaucratic priorities in Japanese television broadcasting', Journal of Japanese Studies 26:1.

Nogami, Shuuichi, (1997)‘Gyosei kaikaku’ no kaimaku to yukue (The Curtain Raising and Whereabouts of 'Administrative Reform'), Shin Nihon Hoki, Tokyo.

Root, Hilton (1998) 'Distinctive institutions in the rise of industrial Asia' in Henry S. Rowen, ed., Behind East Asian Growth: The Political and Social Foundations of Prosperity, Routledge, London.

Samuels, Richard J. (1987) The Business of the Japanese State: Energy Markets In Comparative and Historical Perspective, Cornell University Press, Ithaca, New York.

Schwartz, Frank (1999) Advice and Consent: The Politics of Consultation in Japan, Cambridge University Press, Cambridge.

Secretariat for the Committee on Administrative Reform (1997) Gyosei no yakuwari o toinaosu: gyosei kanyu no arikata ni kansuru kijun (Standards for Appropriate Administrative Intervention), Okurasho Insatsukyoku, Tokyo, 28 March.

Tanaka Kazuaki (1999) 'Shouchou sai hen houan no koko ga mondai da!' (Here's the problem with the bill to reorganize ministries and agencies!) Shukan Toyo Keizai, pp. 62-3, 12 June.

Vogel, Steven K. (1999) 'Can Japan disengage? Winners and losers in Japan's political economy, and the ties that bind them', Social Science Japan Journal 2:1, pp. 3-21.

World Bank (IBRD) (1993) The East Asian Miracle: Economic Growth and Public Policy, Oxford University Press, New York. 


\section{Previous Pacific Economic Papers}

300 A way forward for Japanese agriculture?

Masayoshi Homna, Ray Trewin, Jennifer Amyx, Allan Rae, February 2000 (special volume)

299 Japanese foreign direct investment in the world economy 1951-1997

Roger Farrell, January 2000

298 The genesis of APEC: Australian-Japanese political initiatives

Takashi Terada, December 1999

297 Is shutting Krugman's 'liquidity trap' the answer to Japan's problems?

Dominic Wilson, November 1999

296 Japanese government-business collaboration and the operations of Japanese corporations in Asia: A telecommunications case

Hidetaka Yoshimatsu, October 1999

295 Free trade champion? Australian views of the US crusade against Japan Julia Lowell, September 1999

294 Governance and Australian financial institutions Kevin Davis, August 1999

293 The changing climate for foreign direct investment into Japan

Peter Drysdale, Ray Trewin, Toshi Naito and Dominic Wilson, July 1999

292 The Japanese origins of PAFTAD: The beginning of an Asian Pacific economic community

Takashi Terada, June 1999

291 Not just a question of multilateral free trade: Australia's bilateral trade liberalisation agenda towards Japan

Jamie Anderson, May 1999

290 Perspectives on Japanese investment, employment and management in Australia Roger Farrell and Peter Drysdale, April 1999

289 Predicting banking crises: Japan's financial crisis in international comparison Michael Hutchinson and Kathleen McDill, March 1999

288 Japan's financial reform Volume I

Hugh Patrick, Takatoshi Ito, February 1999

287 International trade and environmental policy: how effective is 'eco-dumping'?

Xinpeng $\mathrm{Xu}$, January 1999 
286 Open regionalism going global: APEC and the new transatlantic economic partnership Andrew Elek, December 1998

285 Realism and postwar US trade policy John Kunkel, November 1998

284 Attracting FDI: Australian government investment promotion in Japan, 1983-96 Jamie Anderson, October 1998

283 The Multi-function polis 1987-97: an international failure or innovative local project?

Paul Parker, September 1998

282 Organisation, motivations and case studies of Japanese direct investment in real estate 1985-94

Roger Farrell, August 1998

281 Japan's approach to Asia Pacific economic cooperation

Peter Drysdale, July 1998

280 The politics of telecommunications reform in Japan

Hidetaka Yoshimatsu, June 1998

279 Sustainability of growth in the Korean manufacturing sector Chang-Soo Lee, May 1998

278 Export performance of environmentally sensitive goods: a global perspective Xinpeng $\mathrm{Xu}$, April 1998

277 Modelling manufactured exports: evidence for Asian newly industrialising economies

Francis In, Pasquale Sgro and Jai-Hyung Yoon, March 1998

276 Laos in the ASEAN free trade area: trade, revenue and investment implications Jayant Menon, February 1998

275 Globalisation

Heinz Arndt, January 1998

274 The WTO and APEC: What role for China?

Stuart Harris, December 1997

273 The APEC air transport schedule Christopher Findlay, November 1997

272 Japanese foreign direct investment in real estate 1985-1994 Roger Farrell, October 1997

271 China and East Asia trade policy volume 4: Trade reform and liberalisation in China Yang Shengming, Zhong Chuanshui, Yongzheng Yang, Feng Lei, 
Yiping Huang, and Pei Changhong, September 1997

(Special volume)

270 The politics of economic reform in Japan

T.J. Pempel, Tony Warren, Aurelia George Mulgan, Hayden Lesbirel,

Purnendra Jain and Keiko Tabusa, August 1997

269 Diplomatic strategies: the Pacific Islands and Japan

Sandra Tarte, July 1997

268 Interest parity conditions as indicators of financial integration in East Asia

Gordon de Brouwer, June 1997

267 Consensus in conflict: competing conceptual structures and the changing nature of Japanese politics in the postwar era

Lindy Edwards, May 1997

266 The role of foreign pressure (gaiatsu) in Japan's agricultural trade liberalisation

Aurelia George Mulgan, April 1997

265 Transformation in the political economy of China's economic relations with Japan in the era of reform Dong Dong Zhang, March 1997

264 Economic relations across the Strait: interdependence or dependence? Heather Smith and Stuart Harris, February 1997

263 Has Japan been 'opening up'?: empirical analytics of trade patterns Jayant Menon, January 1997

262 Postwar private consumption patterns of Japanese households: the role of consumer durables Atsushi Maki, December 1996

261 East Asia and Eastern Europe trade linkages and issues Jocelyn Horne, November 1996

260 National choice Wang Gungwu, October 1996

259 Australia's export performance in East Asia Peter Drysdale and Weiguo Lu, September 1996

258 Public infrastructure and regional economic development: evidence from China Weiguo $\mathrm{Lu}$, August 1996

257 Regional variations in diets in Japan Paul Riethmuller and Ruth Stroppiana, July 1996

256 Japanese FDI in Australia in the 1990s: manufacturing, financial services and tourism 
Stephen Nicholas, David Merrett, Greg Whitwell, William Purcell with Sue Kimberley, June 1996

255 From Osaka to Subic: APEC's challenges for 1996 Andrew Elek, May 1996

254 NAFTA, the Americas, AFTA and CER: reinforcement or competition for APEC? Richard H. Snape, April 1996

253 Changes in East Asian food consumption: some implications for Australian irrigated agriculture Philip Taylor and Christopher Findlay, March 1996

252 Behaviour of Pacific energy markets: the case of the coking coal trade with Japan Richard J. Koerner, February 1996

251 Intra-industry trade and the ASEAN free trade area Jayant Menon, January 1996

250 China and East Asia trade policy, volume 3: China and the world trade system Various authors, December 1995 (special volume)

249 China and East Asia trade policy, volume 2: Regional economic integration and cooperation Various authors, November 1995 (special volume)

\section{Annual subscription rate for twelve issues:}

Individuals $\mathrm{A} \$ 60.00$

Institutions A $\$ 100.00$

\section{Cost for single issues:}

$\mathrm{A} \$ 15.00$

A $\$ 10.00$ (Students)

All prices include postage

Available from: Publications Department

Australia-Japan Research Centre

Asia Pacific School of Economics and Management

The Australian National University

Canberra ACT 0200, Australia

Facsimile: (61 2) 62490767

Telephone: (61 2) 62493780

Email: ajrc@anu.edu.au

URL: http://ajrcnet.anu.edu.au/ 